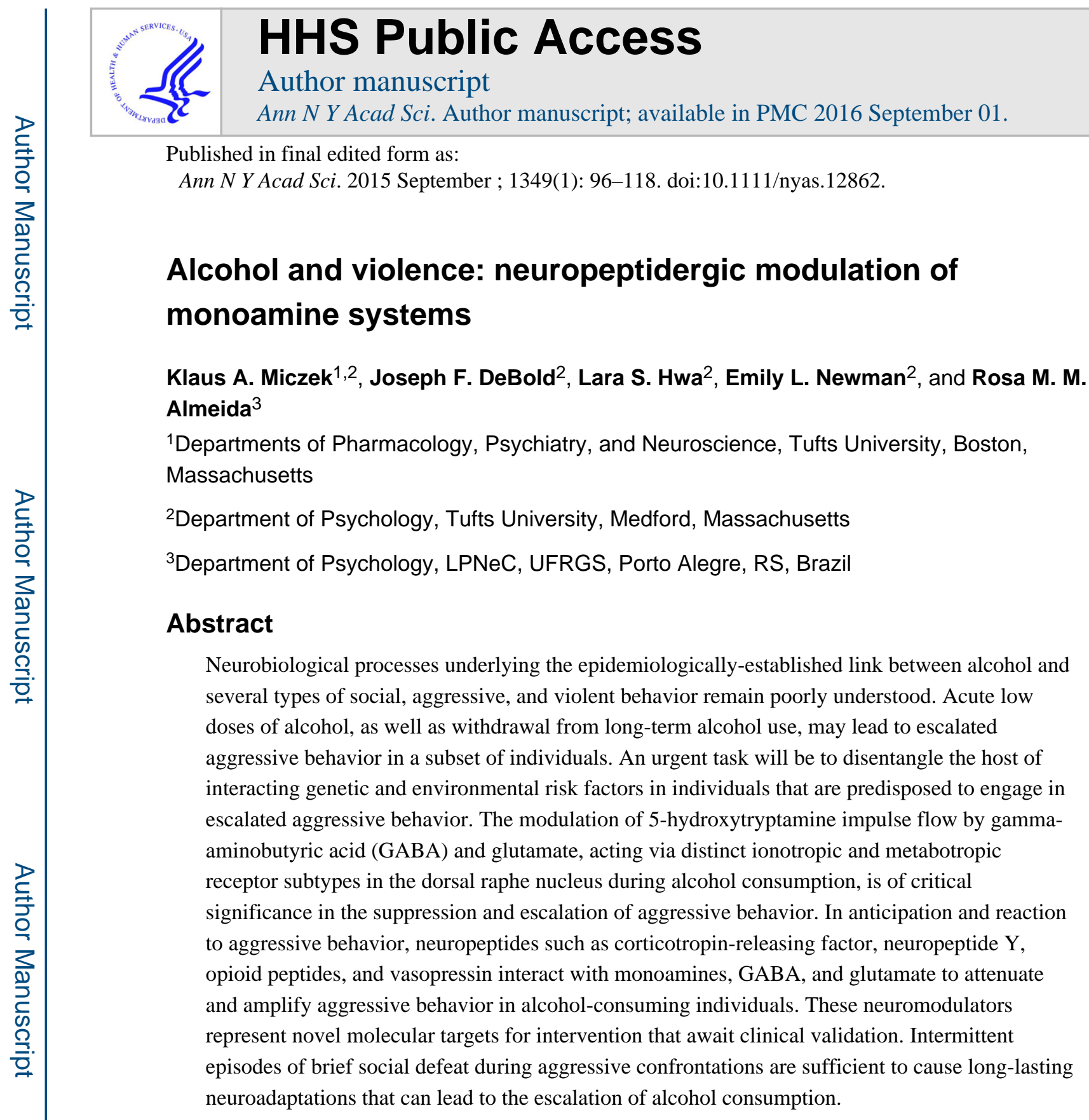

\title{
Keywords
}

violence; aggression; alcohol; GABA; glutamate; serotonin

\begin{abstract}
Alcohol has been linked to at least half of all violent assaults, cases of child abuse, and other incidents of domestic violence as well as homicides and murders. ${ }^{1-3}$ This association has persisted over several decades and extends across most regions of the world. While the consumption of alcohol features prominently in many celebratory and salient events in social life, it is the anti-social, destructive nature of alcohol's effects that is of profound concern to the criminal justice system, and as a public health problem. ${ }^{4,5}$ Surprisingly, the
\end{abstract}

Address for correspondence: K. A. Miczek, Tufts University, 530 Boston Ave (Bacon Hall), Medford, MA 02155.

klaus.miczek@tufts.edu. 
neurobiological processes underlying the link between alcohol and social, aggressive and violent behavior remain poorly understood, and there is no effective clinical treatment for violence induced or heightened by alcohol.

Initially, this review highlights several fundamental and essential pharmacological features of the link between alcohol and aggression, ranging from the acute effects to the effects of withdrawal after long-term use. Next, we consider the reinforcing actions of aggression and alcohol, both acting on neural circuits in mesolimbic monoaminergic systems. Furthermore, this review links alcohol and aggression to a postulated deficiency in brain serotonin and will outline the different serotonin subsystems and their receptor subtypes. Serotonin (5hydroxytryptamine, 5-HT) and other canonical monoaminergic pathways are modulated by gamma-aminobutyric acid (GABA) and glutamate, and these excitatory and inhibitory amino acids are critical sites of action for alcohol to escalate aggressive behavior. Finally, we consider some of the prominent neuropeptides and neuroactive steroids and their modulatory action on alcohol and aggression.

There are several new conclusions about the neurobiological processes that mediate the effects of alcohol on aggressive behaviour

1. Significant aggression-heightening effects are evident after acute, low alcohol doses as well as during withdrawal from long-term alcohol use; alcohol may lead to the distortion of social signals from benign to threatening.

2. A significant subset of individuals engages in alcohol-heightened aggression, while most alcohol-consuming individuals do not exhibit significant changes in aggressive behavior.

3. Subsystems of 5-HT neurons originating in the dorsal raphe nuclei and maturing during specific critical periods appear to contribute to the emergence of aggressive behavior.

4. The modulation of 5-HT impulse flow by GABA and glutamate, acting via distinct ionotropic and metabotropic receptor subtypes is of critical significance in the suppression and escalation of aggressive behavior.

5. In anticipation and reaction to aggressive behavior, neuropeptides such as corticotropin-releasing factor (CRF), neuropeptide Y (NPY), opioid peptides, and vasopressin interact with monoamines, GABA, and glutamate to attenuate and amplify aggressive behavior. These neuromodulators represent novel targets for intervention and await clinical validation.

6. Intermittent episodes of brief social defeat during aggressive confrontations are sufficient to cause long-lasting neuroadaptations that lead to the escalation of alcohol consumption. Activation of the CRF system is necessary for this social stress-induced escalation of alcohol consumption.

\section{Epidemiological background}

A consistent series of epidemiological and criminal statistics documents the association between alcohol and violent crimes starting in the 1950 s and extending to the present; ${ }^{6-11}$ 
Table 1. Clinical diagnoses distinguish among instrumental, calculating, pre-meditated, and proactive "cold" aggressive acts on the one hand, and hostile, affective, impulsive and reactive "hot" aggression on the other. ${ }^{12-14}$ Alcohol profoundly exacerbates the latter subtypes of aggression. Important features of the epidemiological data link alcohol and several major types of violent behavior ranging from homicides, sexual assaults, rapes, and child abuse to other physical assaults. This link is large in magnitude and costly to the individual, family, and society. ${ }^{15-18}$ In addition to the pervasive escalation of many types of impulsive and reactive violent acts, possibly due to the myopic perception of threatening stimuli, ${ }^{19}$ some epidemiological data point to geographic hot spots and epidemics of the alcohol-violence link. ${ }^{20}$ Rather than proposing a neurogenetic deterministic account of the genesis of alcohol-heightened aggressive behavior, this evidence points to several risk factors that may interact with the social context. ${ }^{21,22}$

\section{Discovery of ethanol's action on discrete receptors in the brain: 1980-1990}

A major shift in research on neural sites and mechanisms of ethanol and by implication on the aggressogenic effects of ethanol, began in the 1980s, when the focus on the disordering effects of alcohol was redirected from the lipid component of cell membranes to the action of ethanol on protein components in neuronal membranes. ${ }^{23}$ This latter action was identified at several ionotropic receptors at millimolar concentrations which were more relevant to the excitatory effects of ethanol (Fig. 1).

$\mathrm{GABA}_{\mathrm{A}}$ receptors were among the first ionotropic receptors shown to increase chloride ion (Cl)-flux as a result of action by $20-100 \mathrm{mM}$ ethanol, and this effect was blocked by $\mathrm{GABA}_{\mathrm{A}}$ antagonists. ${ }^{24-27} \mathrm{GABA}_{\mathrm{A}}$ receptors are pentameric ligand-gated ion channel complexes composed of at least 16 subunits, with two alpha and beta subunits plus either a gamma or delta subunit being the most typical compositions for receptors in the mammalian central nervous system (CNS). ${ }^{28}$ With the aid of molecular genetic techniques, it appears feasible to learn which subunits need to be expressed in specific brain regions for alcohol to achieve specific behavioral effects. For example, $\mathrm{GABA}_{\mathrm{A}}$ receptors which contain a delta subunit instead of a gamma subunit are sensitive to concentrations of ethanol that are in the mild to moderately intoxicating range, ${ }^{29,30}$ but see Ref. 31 .

While ethanol has enhancing effects on GABAergic synapses, it has the opposite effect on glutamatergic signaling. Ethanol at concentrations of 10-25 mM inhibits NMDA glutamate receptors. ${ }^{32-35}$ Intoxicating doses of ethanol can reduce glutamatergic neurotransmission in the nucleus accumbens ${ }^{36}$ and amygdala. ${ }^{37}$

$N$-Methyl-D-aspartic acid receptors (NMDAR) are tetrameric ligand-gated ion channel complexes composed of two GluN1 subunits and two GluN2 (A, B, C, or D) subunits; GluN3 (A and B) subunits reduce ligand sensitivity and $\mathrm{Ca}^{2+}$ permeability. ${ }^{38,39}$ As with the $\mathrm{GABA}_{\mathrm{A}}$ receptor, many NMDAR subunit combinations are responsive to ethanol. The recombinant approach has demonstrated that GluN1 is required, but then it is the fundamental obligatory NMDAR subunit. ${ }^{40}$ Of the four isoforms of GluN2 subunit, ethanol can inhibit recombinant GluN1/GluN2A and GluN1/GluN2B NMDA receptors, and those containing GluN2B have been found to be the most sensitive to ethanol in HEK cells, but 
not Xenopus oocyte expression systems. ${ }^{41-45}$ Ethanol sensitivity is lower if the recombinant receptors contain GluN2C or GluN2D subunits instead of GluN2A or 2B. ${ }^{46}$ The conditional knock-out approach suggests that GluN2B subunits play an important role in ethanol's effects on NMDARs in the bed nucleus of the stria terminalis. ${ }^{47}$ In addition, acute low concentrations of ethanol alter NMDA subunit trafficking and can result in a selective internalization of GluN2A subunits, as well as a change in the GluN2A/GluN2B ratio. ${ }^{48}$

Ethanol can also increase neural activity in the VTA and increase dopamine (DA) release in the nucleus accumbens, potentially indicative of the rewarding effects of this drug ${ }^{49-52}$ (see below). These effects appear to be mediated by ethanol's actions on GABAergic and glutamatergic neurons, and in part by ethanol's effects on other ion channels, including G protein-gated inwardly rectifying $\mathrm{K}^{+}$channels (GIRK) ${ }^{53,54}$ and other intracellular signaling pathways. ${ }^{55}$

Similarly, ethanol increases 5-HT release in the nucleus accumbens, ${ }^{56-58}$ and this effect may play a role in modulating DA release in this nucleus. ${ }^{59}$ Some of the effects of ethanol on serotonergic neurotransmission, like those on DA, appear to be indirect. ${ }^{60}$ However, ethanol does directly potentiate $5-\mathrm{HT}_{3}$ receptors, ${ }^{61,62}$ and these receptors, as well some other 5 -HT subtypes, may be important in alcohol abuse. ${ }^{63-67}$ Genetic differences in serotonergic systems across individuals may also explain some of the differences in alcohol intake and abuse $^{68}$ (see below).

Recently, the action of alcohol in the DRN has been explored using electrophysiological techniques. DRN inhibitory transmission is particularly sensitive to ethanol, and this is mediated primarily by synaptic $\mathrm{GABA}_{\mathrm{A}}$ receptors and secondarily by glycine receptors. ${ }^{69} \mathrm{In}$ mice previously exposed to chronic intermittent ethanol vapor there was increased DRN excitability during withdrawal ${ }^{70}$ and decreased spontaneous inhibitory transmission in DRN-containing brain slices from these animals. Further, bath application of ethanol enhanced the frequency of miniature inhibitory postsynaptic currents (mIPSCs) in DRN neurons in slices from ethanol-withdrawn mice, but not ethanol-naive mice. ${ }^{70} \mathrm{Chronic}$, voluntary ethanol intake through intermittent access to two-bottle choice in Sprague-Dawley rats and C57BL/6J mice also can lead to functional DRN changes. ${ }^{71,72}$ Repeated binge drinking during adolescence specifically decreased expression of 5-HT-related genes and of genes encoding the $\mathrm{GABA}_{\mathrm{A}}$ receptor $\mathrm{a} 2, \mathrm{a} 3$, and $a 5$ subunits in the DRN. ${ }^{73}$ However, this contrasts with a recent clinical study demonstrating that adult alcoholics have greater tryptophan hydroxylase 2 mRNA and protein in the DRN, compared to nonpsychiatric controls. ${ }^{74}$ Taken together, these results suggest that ethanol can cause alterations in DRN signaling, both after acute and chronic exposure.

\section{Basic pharmacology of alcohol and aggression}

It has been challenging to determine the exact amount of alcohol circulating in the blood, and the amount acting on pivotal target sites in the brain, of human perpetrators or victims of violence. Instead, estimates rely on retrospective analysis of events that occurred at varying times in the past and involve questionable recall. It is even rarer to learn about precise blood levels of alcohol at the time of apprehension of an alcohol-intoxicated perpetrator or victim 
of aggressive acts or both. In the absence of such data, experimental studies with human subjects, and preclinical studies in animal models, supply important information on the basic pharmacology of alcohol on aggressive behavior, although experimental work on intensely violent acts is ethically unacceptable. We have developed preclinical methods to study escalated aggression after oral consumption of alcohol in a significant subgroup of individual mice, rats, and monkeys. ${ }^{16,75-77}$

Acute exposure to alcohol results in a biphasic dose- and time-dependent relationship between alcohol and most of its behavioral, physiological, and neurochemical effects, among them aggressive behavior. ${ }^{78}$ The level of circulating alcohol is systematically related to the rate and intensity of aggressive behavior in several experimental models. Low doses of alcohol on the ascending limb of the dose-effect curve result in increased aggressive behavior, whereas high doses decrease this behavior as part of its sedative effects in humans, non-human primates, and rodents (Fig. 2). ${ }^{79-83}$ For example, resident mice or rats that were administered ethanol by gavage showed peak escalation of attack bites and sideways threats at the $1.0 \mathrm{~g} / \mathrm{kg}$ dose. Similarly, when outbred Swiss mice were conditioned to selfadminister fixed doses of ethanol prior to confronting an intruder opponent, they engaged in peak levels of aggressive behavior at the $1.0 \mathrm{~g} / \mathrm{kg}$ dose. ${ }^{16,84} \mathrm{In}$ a methodological refinement, outbred Swiss mice self-administered droplets of $6 \% \mathrm{w} / \mathrm{v}$ ethanol voluntarily. After accumulating $1.0 \mathrm{~g} / \mathrm{kg}$ ethanol within 5 minutes, they confronted an intruder opponent and engaged in significantly escalated aggressive behavior. Detailed quantitative analysis of alcohol-heightened aggressive behavior revealed that resident rats fail to terminate aggressive bouts. ${ }^{80}$

Aside from increasing the rate of aggressive behavior, self-administered ethanol also intensifies aggressive acts, based on detailed analysis of the wounds. Among the key criteria for modeling pathological aggression in experimental animals are the lack of threats preceding injurious attacks and the indiscriminate targets for inflicting bodily harm. ${ }^{85,86}$ Slow-motion video analysis reveals that alcohol self-administering resident mice or rats aim their attack bites at vulnerable parts of the intruder's body such as the ventrum and face ${ }^{87}$ (Newman et al. in prep; Fig 3).

Epidemiological and clinical studies primarily focus on recurrent violent incidents in individuals experiencing repeated alcohol intoxication. ${ }^{88}$ It is well-established that half of alcohol-dependent males who cycle through bouts of intoxication and withdrawal commit violent acts. ${ }^{89-92}$ Recently, an experimental protocol was developed to identify peak aggressive behavior in laboratory mice concurrent with glutamatergic convulsive phenomena in withdrawal from two months of intermittent access to $20 \%$ ethanol (w/v). ${ }^{77}$ With increasing length of intermittent access to alcohol, a larger proportion of mice began to engage in aggressive behavior when withdrawing from alcohol (Fig. 4).

While the evidence from preclinical studies is valuable, being based on systematic and controlled drug manipulations and measurements, it is limited by important differences in patterns of voluntary alcohol consumption, alcohol uptake, distribution and metabolism, and neurochemical targets. Animal species differ considerably with regard to the fate of alcohol in the body and the brain, and to the morphological and functional characteristics of the 
neural sites of action for alcohol. ${ }^{23}$ When translating preclinical data to the human condition, it is essential to scale doses and time of peak effect across species very carefully. ${ }^{23}$

\section{Individual differences in ethanol and aggression}

Individuals differ markedly as to whether the consumption of a given dose of alcohol will escalate aggressive and violent behavior. ${ }^{93}$ Reliable and predictive genetic, physiological, or behavioral markers remain elusive, making it difficult to identify individuals with a predisposition for heightened aggressive and violent behavior in the early phase of ethanol action or during withdrawal. Retrospective clinical studies have associated polymorphisms in individuals with a propensity to engage in escalated aggressive and violent behavior. For example, genotyping the $B D N F$ gene polymorphism, G196A, revealed that Japanese alcoholics with violent tendencies were more likely to be homozygous for the A allele compared to non-violent individuals. ${ }^{94}$ In a Swedish sample of adolescents with alcoholrelated problem behaviors, a short variant of gene encoding MAO-A was detected, particularly when the youngsters grew up in abusive families. ${ }^{95}$ Longitudinal studies with a focus on childhood abuse and continuing through adolescence into early adulthood would be particularly informative in identifying interactions between developmental and genetic risk factors that engender alcohol-related violence.

Preclinical studies with mice, rats, and monkeys identify subgroups of individuals for whom a moderate dose of alcohol reliably escalates aggressive behavior, whereas most others do not show this effect ${ }^{16}$ (Fig. 5). This variability in laboratory rats and mice has led to our distinction between alcohol-heightened aggressors (AHA) and alcohol-non-heightened aggressors (ANA) on account of the persistent, large increase in injurious attack behaviors after every exposure to a moderate $1 \mathrm{~g} / \mathrm{kg}$ dose of ethanol. ${ }^{76,80,81}$ So far, these subtypes have been characterized in terms of pharmacological sensitivity with serotonergic, GABAergic, and glutamatergic compounds. ${ }^{76,84,96-102}$ In rhesus monkeys, intense consumption of alcohol leads to long bursts of impulsive aggressive behavior primarily in those individuals with a history of social isolation early in life. ${ }^{103}$ It will be most instructive to identify biomarkers that predict whether an individual will engage in alcohol-heightened aggressive behavior.

\section{Victims of aggression: escalated alcohol consumption as a result of social stress}

While the aggressogenic effects of alcohol continue to be the focus of clinical and basic research with animal models, ${ }^{16,104}$ a critical role of alcohol emerges in the individual who is not the perpetrator, but the target of aggressive acts. Early preclinical studies have demonstrated how administration of ethanol to mice, rats, or monkeys alters their behavior in confrontations with an aggressive opponent. ${ }^{105-107}$ The higher the dose of alcohol in the intruder mouse or rat or the subordinate monkey, the more frequently these individuals provoked attacks and threats. The perception and production of social signals and pheromones contribute to the escalation of aggressive interactions. The analysis of social cues and the interpretation and integration of these cues promises to reveal how alcohol 
alters provocative signals, and the response to these signals. Giancola ${ }^{19}$ proposes that distorted perceptions of social signals - a type of myopia — emerge as a key determinant of alcohol-escalated aggressive behavior.

When exposed to repeated episodes of aggression and displaying salient characteristics of social stress, individuals who are the target of attacks or threats can undergo neural adaptations that cause them to consume large amounts of alcohol and to exhibit signs of increased motivation for alcohol. ${ }^{108,109}$ There is considerable debate about the impact of different types of environmental stressors on alcohol consumption. ${ }^{110-113}$ In order to capture the well-documented and often reiterated link between stress and alcoholic drinking in humans, several preclinical efforts have focused on social stress. ${ }^{114}$ One approach focuses on continuous subordination stress that extends over several weeks and months in mice, rats, and monkeys. Low-ranking squirrel monkeys or macaques consume more alcohol than highranking individuals. ${ }^{115,116}$ Several studies report increases in consumption of alcohol at concentrations ranging from $2-20 \% \mathrm{v} / \mathrm{v}$ in socially subordinate members of a group of mice or rats. ${ }^{117,118}$ Even though these increases in intake relative to non-stressed controls are statistically significant, they are usually insufficient to produce either intoxication or dependence.

A second approach in animal models involves repeated acute episodes of social defeat stress that result in escalated alcohol drinking. ${ }^{119-122}$ When corticotropin releasing factor receptor 1 (CRF-R1) gene knock-out mice bred onto an outbred CD-1 background were subjected to brief episodes of social defeat stress on three consecutive days, they began to consume $\sim 3$ $\mathrm{g} / \mathrm{kg} /$ day of $8 \%$ alcohol (v/v), compared to the $1 \mathrm{~g} / \mathrm{kg} /$ day pre-stress baseline. ${ }^{119}$ This increase manifested itself only after a three-week interval between the social stress experience and the alcohol consumption. More recently, a series of studies identified the parameters of social defeat stress that induced escalated alcohol consumption in mice without any restriction in fluid intake and engendered a preference for alcohol relative to concurrently available water. Brief episodes of social defeat stress every day or every other day were sufficient to escalate consumption of $20 \%$ unsweetened alcohol (w/v) up to 15 $\mathrm{g} / \mathrm{kg} /$ day in CFW mice and up to $30 \mathrm{~g} / \mathrm{kg} /$ day in C57BL/6J mice (Fig. 6). ${ }^{77,120}$ Several features of these latter studies are noteworthy: the escalated alcohol intake began after several weeks without stress and continued in the absence of any further exposure to social stress, suggesting the induction of an enduring neuroadaptation. Pharmacological antagonism and genetic deletion experiments implicate the CRF system in the induction and expression of the neuroadaptations that result from exposure to brief episodes of social defeat stress and eventually lead to persistently escalated alcohol consumption (see below).

\section{Alcohol-heightened aggression as a source of satisfaction and pleasure: Mesocorticolimbic circuits}

More than 50 years ago John Paul Scott ${ }^{123}$ recognized that "aggression not only produces dangers which must be avoided, but pleasures which can be enjoyed." Among the causative factors for alcohol-heightened aggression are the rarely-investigated neural mechanisms mediating the rewarding effects of aggressive behavior. ${ }^{124-128}$ By contrast, the neural mechanisms for the rewarding effects of alcohol consumption are more adequately 
characterized. Many facets of alcohol's reinforcing effects have been examined in a range of species and conditions. ${ }^{50,129-134}$ Individuals may prefer alcohol over other commodities, seek out the opportunity to self-administer ethanol, exert themselves to obtain alcohol, or resist the negative consequences of alcohol consumption. All of these behaviors are based on neural interactions in mesencephalic-limbic-cortical loops. These circuits include sensory components, and most alcohol is consumed in flavored concoctions; alcohol solutions affect neural circuits that regulate ingestive homeostasis of intra- and extracellular fluids and calories; most importantly, the pharmacological actions of alcohol on targets in the mesocortical and mesolimbic monoaminergic pathways appear to be necessary for its reinforcing effects. While an "alcohol receptor" has not been discovered, several ionophoric receptors in GABAergic, glutamatergic, and monoaminergic neurons are the targets of millimolar concentrations of alcohol, as previously mentioned. ${ }^{23}$ Alcohol's reinforcing effects depend on the integrity of dopaminergic neurons in the VTA that are modulated by GABAergic and glutamatergic afferents, and that project to the core and shell of the nucleus accumbens, as well as to the medial prefrontal cortex. ${ }^{135}$ These basic networks of monoamines-excitatory and inhibitory amino acids subserving the reinforcing effects of alcohol—are modulated by a large number of neuropeptides. ${ }^{132,136}$

To what extent do the neural mechanisms mediating alcohol's reinforcing effects overlap or interact with those that are responsible for aggressive and violent acts, which in themselves function as reinforcers? So far, only a few candidate neural mechanisms have been explored in experimental models that identify aggressive acts as reinforcers. Positive allosteric modulation by benzodiazepines and allopregnanolone of the $\mathrm{GABA}_{\mathrm{A}}$ receptor has proven effective in escalating the rate of responding that was reinforced by the opportunity to engage in aggressive behavior. ${ }^{124,137}$ As the opportunity for aggressive behavior approached, the rate of responding accelerated and plasma levels of corticosterone were elevated; and corticosterone elevations appeared to be required for responding that is motivated by the opportunity to engage in aggressive behavior and for the escalated aggression (Fig. 7). ${ }^{137}$ It is likely that the allosterically- modulated $\mathrm{GABA}_{\mathrm{A}}$ receptors are altering DA and 5-HT impulse flow.

Direct antagonism of DA receptor subtypes reduces the rate of responding that is reinforced by the opportunity to engage in aggressive behavior; microinjections of low doses of DA D1- or D2-like receptor antagonists into the nucleus accumbens (NAcc) preferentially reduced the behavioral effort to gain access to an aggressive confrontation. ${ }^{128}$ It appears reasonable to suggest that alcohol-heightened aggressive behavior may require intact DA activity in the mesolimbic pathway, particularly in view of heightened release of DA in the NAcc in rats that consume alcohol and subsequently engage in escalated aggressive Recently-developed optogenetic methods promise to differentiate the aggression-specific DA cells from those that mediate other motivated behavior and motor functions.

Escalated aggressive behavior with pathological features is evident in mouse and rat strains that are selectively bred for high aggression. ${ }^{139}$ So far, the reinforcing nature of pathological aggression can only be inferred from the short-latency, high-frequency, and high-intensity of persistent and injurious attacks; ${ }^{127}$ more definitive information will have to be obtained from a formal analysis of the contingencies between pathologically escalated aggressive 
behavior and its consequences. Most evidence for neurobiological mechanisms mediating pathologically escalated aggressive behavior has focused on tonic brain 5-HT activity and on 5-HT autoreceptors. ${ }^{140}$ In prefrontal cortex, increased 5-HT has been detected when escalated aggressive behavior is initiated, whereas termination of aggressive bouts and return to tonic levels of 5-HT is associated with reduced neural activity in the serotonergic soma of raphe cells. ${ }^{98,141}$ The extent to which alcohol's violence- and aggressionheightening effects depend on serotonergic activity has been studied both in clinical and preclinical models for several decades.

\section{The 5-HT-alcohol link: from the deficiency hypothesis to discrete subsystems}

No other neurotransmitter has been more intensively investigated than 5-HT when characterizing neural mechanisms of violence and aggression, ${ }^{98,140,142-144}$ including the link between alcohol and aggression. ${ }^{104,145-148}$ Historically, the most frequently reiterated hypothesis attributed a predisposition for violent behavior to a deficiency in 5-HT in alcohol-consuming individuals, supported primarily by post-mortem assays of tissue samples or lumbar CSF.

Shortly after the discovery of 5-HT in the brain, the calming role of this biogenic amine was highlighted, ${ }^{149}$ and then extended to aggressive individuals. ${ }^{150}$ Consistent evidence in many species, ranging from invertebrates, fish, and rodents to non-human primates and humans, documents an effective reduction in aggressive behavior after treatment with drugs that target $5-\mathrm{HT}_{1 \mathrm{~A}}$ or $5-\mathrm{HT}_{2 \mathrm{~A} / \mathrm{C}}$ receptor subtypes and transporter sites. ${ }^{140,151-153}$ Conversely, monkeys and humans with the short allele of the serotonin transporter polymorphism (5HTTLPR) are characterized by heightened aggressive behavior. ${ }^{154,155}$ However, like clinically-employed pharmacotherapeutic treatments with potent anti-aggressive effects (including anti-psychotics, $\beta$-adrenergic blockers, steroid derivatives, and benzodiazepines), nearly all of the $5-\mathrm{HT}_{1 \mathrm{~A}}$ receptor agonists, $5-\mathrm{HT}_{2 \mathrm{~A}}$ receptor antagonists, and selective serotonin reuptake inhibitors (SSRIs) decrease aggressive behavior in dose ranges that have problematic side-effect profiles. ${ }^{156}$ Agonists of 5- $\mathrm{HT}_{1 \mathrm{~B}}$ receptors appear to result in behaviorally more selective anti-aggressive effects in experimental studies with mice and humans. ${ }^{76,102,157-159}$

Research on the anatomical sites of action for alcohol's effects on escalated aggression has focused on the regions within the prefrontal cortex, amygdala, septum, and hypothalamus. ${ }^{148,156}$ Imaging studies in patients with intermittent explosive disorder show deficient activation of medial prefrontal cortex concurrent with heightened activity in the amygdaloid complex. ${ }^{160-162}$ The same regions are activated by acute alcohol intake, as indicated by converging evidence from several methodologies. Expression of immediate early genes in laboratory rodents that engage in escalated aggressive behavior identify several interconnected brain regions along the center of the neuraxis, ranging from the periaqueductal grey to the ventral tegmentum, hypothalamus, preoptic area, septum, amygdala, and prefrontal cortex. ${ }^{141,153,163-165}$ Expression of 5-HT receptor subtypes is reduced in prefrontal cortex of those individual mice who engage consistently in alcoholheightened aggression relative to those who do not. ${ }^{99}$ 
Intracerebral microinjection studies localized the neural pathway projecting from the DRN to the striatum and prefrontal cortex as pivotal in the actions of $5-\mathrm{HT}_{1 \mathrm{~A}}$ and $5-\mathrm{HT}_{1 \mathrm{~B}}$ receptors. Activation of these subtypes at the $5-\mathrm{HT}_{1 \mathrm{~A}}$ somatodendritic autoreceptors, as well as pre- and post-synaptic 5- $\mathrm{HT}_{1 \mathrm{~A}}$ and $5-\mathrm{HT}_{1 \mathrm{~B}}$ receptors, effectively reduced alcoholheightened aggressive behavior in mice and rats. ${ }^{98,101,166,167}$ Studies with muscimol microinjections suggest that escalated aggression as a result of alcohol consumption involves GABAergic modulation of 5-HT in the DRN. ${ }^{98}$ A role of glutamatergic modulation of 5-HT impulse flow to the MPFC in alcohol-heightened aggression is indicated by effects of memantine and ketamine in AHA mice (Newman et al. in prep). An emerging hypothesis regarding the mechanism for alcohol-heightened aggression focuses on subpopulations of 5HT projections to the forebrain and their modulation by specific GABA and glutamate receptors.

\section{Alcohol-heightened aggression and GABA}

A great deal of attention has been paid to the effects of alcohol on GABA receptors for several reasons. As discussed below, alcohol can allosterically modulate $\mathrm{GABA}_{\mathrm{A}}$ receptors but a number of effects of alcohol on the brain and behavior are similar to those of more specific drugs that act relatively specifically on $\mathrm{GABA}_{\mathrm{A}}$ receptors. For example, the sedative and hypnotic effects of alcohol are similar to those of barbiturates and benzodiazepines, and both of these classes of drugs also act on $\mathrm{GABA}_{\mathrm{A}}$ receptors as positive allosteric modulators. In addition, chronic exposure to alcohol alters the expression of $\mathrm{GABA}_{\mathrm{A}}$ receptor subunits, ${ }^{168-171}$ although the expression of these subunits appears to depend on the pattern and dose of alcohol, as well as whether withdrawal occurs.

\section{$\mathrm{GABA}_{A}$ receptors}

Alcohol can increase aggressive behavior not only in people but in a number of laboratory animal species. However, the magnitude of this effect varies across individuals ${ }^{80,172}$. We have been investigating the likely bases for individual differences in sensitivity to the proaggressive effects of alcohol in laboratory rodents and it is quite clear is that alcohol generally has biphasic effects on aggressive behavior (see below). Although these drugs can be pro-aggressive in some individuals, ${ }^{173,174}$ higher doses of benzodiazepines and $\mathrm{GABA}_{\mathrm{A}}$ agonists in conjunction with neuroleptics have an inhibitory effect, and so are often used to sedate violent patients. ${ }^{175-177}$

Benzodiazepines can act as positive modulators of $\mathrm{GABA}_{\mathrm{A}}$ receptors, but not all $\mathrm{GABA}_{\mathrm{A}}$ receptors have a benzodiazepine binding site. Benzodiazepine action requires that the $\mathrm{GABA}_{\mathrm{A}}$ receptor include a $\gamma 2$ subunit as well as $\alpha$ and $\beta$ and subunits. ${ }^{178-180}$ However, there is debate as to which a subunit of the $\mathrm{GABA}_{\mathrm{A}}$ receptor is necessary for the benzodiazepine to exert sedative, anxiolytic, amnestic, or anticonvulsive effects or to lead to abuse. ${ }^{181}$ We have examined whether $\mathrm{GABA}_{\mathrm{A}}$ receptor subunit composition might also influence the effect of alcohol on aggressive behavior. We have found that benzodiazepine antagonists which preferentially act on $\mathrm{GABA}_{\mathrm{A}}$ receptors with a 1 subunits can reduce the pro-aggressive effects of alcohol in mice. ${ }^{84}$ In addition, point mutations to the genes encoding a 1 (H101R) or a 2 (H101R), but not a 3 (H126R) subunits in mice can block the aggression-heightening effects of midazolam (Newman et al. 2015). ${ }^{182}$ These findings may 
be useful in the eventual development of therapies to specifically reduce the association between alcohol and violence.

Direct agonists of $\mathrm{GABA}_{\mathrm{A}}$ receptors, such as musicmol, can also influence aggressive behavior. Much of the early research on the effects of muscimol on aggressive behavior in laboratory rodents reported inhibitory effects. ${ }^{183-186}$ However, when microinjected into the DRN of male mice, $0.006 \mathrm{nmol}$ of muscimol potentiated aggressive behavior. ${ }^{98,187}$ Importantly, this effect only occurred in mice that showed alcohol-heightened aggression. ${ }^{98}$ In addition, muscimol microinjections were behaviorally ineffective if they missed the DRN. This suggests that the DRN may be a particularly important site in the link between GABA $_{A}$ receptors and the effects of alcohol on aggression.

Another tool that has been employed to study the possible link between alcohol- heightened aggression and $\mathrm{GABA}_{\mathrm{A}}$ receptors is the neuroactive steroid allopregnanolone (ALLO), produced both in the brain and peripherally and the most potent positive modulator of GABA $_{\mathrm{A}}$ receptors known. ${ }^{188-193}$ Disrupted ALLO is associated with depression, stress, and anxiety. ${ }^{194}$ Alcohol can increase ALLO levels in laboratory rodents and altered brain concentrations of ALLO might be a mechanism through which alcohol exerts behavioral effects such as sedation, anxiolysis, and analgesia. Likewise, some pharmacological effects of alcohol may be caused by alcohol-induced increases in ALLO synthesis. ${ }^{195,196}$ Forcedswim stress elevates ALLO in the brain, ${ }^{197}$ and decrements in its biosynthesis, specifically in the basolateral amygdala, can affect aggressive behavior. ${ }^{198,}{ }^{199}$ We have seen that moderate doses of ALLO increase aggressive behavior and this effect occurs primarily in the subset of mice that previously have been classified as alcohol-heightened aggressors. ${ }^{200}$ When tested in combination with alcohol, ALLO shifted the alcohol dose-response curve to the left. In addition, higher doses of ALLO, like higher doses of alcohol, inhibit aggressive behavior. That finding is similar to ALLO reducing the frequency of attacks in isolationenhanced aggression. ${ }^{201}$ This neurosteroid appears to be stress-responsive and plays a major role in regulating the hypothalamic-pituitary-adrenal (HPA) axis. ${ }^{202}$ It is possible that individual differences in ALLO may influence stress resilience. It will be important to tease apart the specific neural mechanisms for how alcohol and ALLO affect escalated aggressive behavior.

\section{$\mathrm{GABA}_{B}$ receptors}

In addition to the ionotropic $\mathrm{GABA}_{\mathrm{A}}$ receptor, $\mathrm{GABA}$ actions are also mediated by the metabotropic G-protein coupled $\mathrm{GABA}_{\mathrm{B}}$ receptor. The $\mathrm{GABA}_{\mathrm{B}}$ receptor agonist baclofen has received some attention as a possible treatment for alcohol dependence, ${ }^{132,203,204}$ although some studies have not found it to be significantly better than placebo. ${ }^{205}$ Baclofen also has been reported to reduce the severity of alcohol withdrawal symptoms in patients. ${ }^{203,206,207}$ In rats, baclofen usually reduces aggressive behavior. ${ }^{185,208,209}$ However, our research demonstrates that systemically administered baclofen can actually have a biphasic dose-effect on aggression in male mice. ${ }^{210}$ Microinjection of baclofen into the DRN can specifically increase aggressive behavior. ${ }^{98,187}$ However, that effect does not depend on alcohol and occurs in mice independent of whether they are alcohol-heightened aggressors. 


\section{Alcohol-heightened aggression and glutamate NMDA receptor}

The rationale for considering glutamate and its receptors as relevant to the mechanisms mediating alcohol-heightened aggressive behavior derives from the discovery that alcohol (5-50 mM) antagonizes NMDARs, possibly via the GluN1-glycine site. ${ }^{34,211-214}$ A postmortem analysis of hippocampal tissue from alcoholics and cocaine addicts revealed upregulation of GRIN2B (gene for GluN2B) in all individuals and specific upregulation of GRIN2D (gene for GluN2D) in alcoholics. ${ }^{215,216}$ In addition, GRIN2A polymorphisms may be associated with disruptions in aversion learning and may predict the development of an alcohol use disorder. ${ }^{217,218}$ Polymorphisms of GRIN2B may serve as an indicator for the effectiveness of acamprosate in the treatment of alcohol use disorders. ${ }^{219}$ Preclinical investigations point to the importance of NMDARs in species-typical social behavior. Heterozygous deletion of the GluN1 subunit renders the receptor insensitive to the crucial co-agonist, glycine and thereby reduces the proportion of functional NMDARs. ${ }^{220}$ GluN1 hypomorphic mice consume more alcohol and spend less time in social interactions relative to their genetically unaltered counterparts. ${ }^{220,221}$ Pharmacological blockade of NMDAR can similarly dysregulate social and agonistic behavior. When mice consume a modest dose of alcohol $(1 \mathrm{~g} / \mathrm{kg})$ and are treated with the uncompetitive NMDAR antagonist memantine their aggressive behavior toward a submissive male conspecific escalates. ${ }^{96}$ Furthermore, when alcohol-dependent mice are challenged with a moderate dose of memantine $(5 \mathrm{mg} / \mathrm{kg})$ during withdrawal from access to alcohol following 8 weeks of access, their aggressive behavior escalates (Fig. 9). ${ }^{77}$ Collectively, these findings point to the genetically or pharmacologically suppressed NMDAR as pivotal in behavioral dysregulation as indicated by increased alcohol self-administration, more intense social anxiety-like behavior, and escalated aggressive behavior.

Conversely, several findings point to the therapeutic value of NMDAR antagonists as suggested by the anti-craving effects of acamprosate, memantine, and neramexane (MRZ 2/579) in rats. ${ }^{22,223}$ Additionally, treatment with the uncompetitive antagonist MK-801 (dizocilpine) can increase social interactions between adolescent rats, suggesting reduced social anxiety. ${ }^{224}$ Importantly, in patients diagnosed with alcohol use disorders, memantine and ketamine treatments reduce both cravings for alcohol and alcohol consumption. ${ }^{225-227}$

These divergent interactions between alcohol and NMDAR antagonists may depend on the expression of the GluN2 subunit. Receptors containing GluN2A or GluN2B are more sensitive to the inhibitory action of alcohol and exhibit regionally specific expression patterns. ${ }^{228}$ GluN2A-containing NMDARs are expressed throughout the CNS of rats, while GluN2B subunits are localized preferentially in the forebrain, specifically in the prelimbic and orbital regions of the prefrontal cortex. ${ }^{229}$ Glutamatergic pyramidal cells within these prefrontal cortical areas are activated during aggressive encounters in rats. ${ }^{230}$ Excitatory inputs, particularly from the PFC to the DRN may facilitate the initiation and termination of aggressive behavior. ${ }^{231}$ We hypothesize that dysregulation of cortical inhibition of GluN1/ GluN2B-containing NMDA receptors may result in alcohol-induced social disinhibition and escalated aggression. Individual differences in GluN2 subunit expression may determine the behavioral effects of drugs such as ethanol and memantine in interaction with an individual's predisposition for aggressive behavior and other psychopathologies. ${ }^{232}$ 


\section{Alcohol-heightened aggression and neuropeptides: CRF and opioid peptides}

Stress-related neuropeptide systems have been implicated in alcohol-related behaviors, most prominently CRF and urocortin, NPY, nociception/orphanin, and neurokinin. ${ }^{233}$ These and other neuropeptides have been implicated in the regulation and dysregulation of social behaviors, especially vasopressin, oxytocin, and substance P. ${ }^{234-236}$ Most of the evidence points to a significant role of CRF and opioid peptides in the modulation of alcohol-related aggression.

\section{Corticotropin-releasing factor}

CRF is the initial link in the cascade of neural, endocrine, and behavioral responses to stressful stimuli, ${ }^{237,238}$ especially those related to pro-social and conflict situations. ${ }^{239,240}$ CRF biphasically modulates aggression in various species, ${ }^{241,242}$ with low doses increasing and high doses decreasing agonistic behaviors in rats. ${ }^{243}$ Further, most CRF-R1 antagonists effectively reduce aggression in socially organized species. ${ }^{244-246}$ One way CRF-R1 antagonism prevents alcohol-heightened aggression is, in part, its facilitation of 5-HT impulse flow from the DRN to the mPFC. ${ }^{247}$ The mPFC has emerged as a critical site through which alcohol-induced impairments can contribute to emotional outbursts and violence. ${ }^{126,248}$ Alcoholic, impulsive offenders ${ }^{249}$ and perpetrators of domestic violence ${ }^{250}$ are characterized by dysregulated CRF levels compared to healthy controls. Enhanced aggression, compared to species-typical aggression, may recruit stress-related circuits resulting in a loss of inhibitory control.

\section{Opioid peptides}

Brain opioid peptides acting on mu, delta, or kappa opioid receptors (MOR, DOR, KOR) are critically involved in the regulation of social behaviors and mood disorders. ${ }^{251,252}$ Increased aggression after acute opiates has been documented in several species such as fish, ${ }^{253-255}$ cats, ${ }^{256}$ pigs,${ }^{257}$ crickets,,${ }^{258}$ and mice, ${ }^{259}$ which implicate endogenous opioids in social conflict. By contrast, opioid antagonists reduce alcohol-heightened aggression primarily in some individuals, possibly with a distinctive pattern of expression for genes encoding MOR, DOR and KOR ${ }^{260-262}$ Research is limited for alcohol-heightened aggression, but alcohol interferes with endogenous opioid mechanisms, including the acute release of $\beta$ endorphin. ${ }^{263}$ We hypothesize that endorphins acting on MOR are of particular relevance to alcohol-heightened aggression, and represent important targets for intervention. Social conflict activates antinociception through opioid mechanisms. ${ }^{261,264,265}$ Opioid receptor activation in aggressive encounters may lead to exaggerated responses to threatening environmental stimuli. Naltrexone can reduce self-injurious behavior, ${ }^{266}$ so the prominent interaction between alcohol and endogenous opioids may enable opioid antagonists to suppress alcohol-related aggression. 


\section{Future agenda}

One of the urgent tasks will be to characterize the individuals who are predisposed to engage in alcohol-heightened aggressive behavior. To disentangle the host of interacting genetic and environmental risk factors will require a concerted effort at every level of analysis.

In preclinical studies, novel neurobiological tools such as optogenetic stimulation and inhibition of chemically specific cell groups in discrete nodes of neural microcircuits promise to characterize effective targets of intervention to attenuate alcohol-heightened aggressive behavior.

Novel molecular targets in the neural microcircuits for escalated aggressive behavior are likely to emerge from studies with neuropeptidergic modulation of GABA and glutamate cells that stimulate or inhibit monoaminergic pathways. Alternatively, it will be useful to explore steroid systems and endocannabinoids for their role in alcohol-heightened aggression.

The validity of experimental models of alcohol-heightened aggression derives from their potentially injurious and harmful nature. The ethical dilemma of on the one hand studying alcohol-escalated aggressive behavior in experimental models and on the other hand following the principle of harm reduction will require careful and thorough examination in each case.

\section{References}

1. Pernanen, K. Alcohol and crimes of violence. In: Kissin, B., editor. Social Aspects of Alcoholism. New York: Plenum Press; 1976. p. 351-444.

2. Roizen, J. Issues in epidemiology of alcohol and violence. In: Martin, SE., editor. Alcohol and interpersonal violence: Fostering multidisciplinary perspectives. Research Monograph No. 24. Rockville, MD: National Institutes of Health, National Instiute on Alcohol Abuse and Alcoholism; 1993. p. 3-36.

3. Rossow, I.; Bye, EK. The problem of alcohol-related violence: An epidemiological and public health perspective. In: McMurran, M., editor. Alcohol-Related Violence: Prevention and Treatment. Chichester: Wiley-Blackwell; 2013. p. 1-18.

4. Holder HD. Alcohol and violence: a complex nexus of drinking environment and drinking pattern. Addiction. 2008; 103:78-79. [PubMed: 18081612]

5. Shield KD, Parry C, Rehm J. Chronic diseases and conditions related to alcohol use. Alcohol Res. 2013; 35:155-173. [PubMed: 24881324]

6. Tinklenberg, JR.; Ochberg, FM. Patterns of adolescent violence: A California sample. In: Hamburg, DA., editor. Biobehavioral Aspects of Aggression. New York: Alan R. Liss; 1981. p. 121-140.

7. Shupe LM. Alcohol and Crime. A study of the urine alcohol concentration found in 882 persons arrested during or immediately after the commission of a felony. J Crim Law Criminol Police Sci. 1954; 44:661-664.

8. Livingston LR. Measuring domestic violence in an alcoholic population. J Sociol So Welf. 1986; 13:934-953.

9. Rossow I. Alcohol and homicide in Russia. Addiction. 2004; 99:937. [PubMed: 15265088]

10. Norström T. The role of alcohol in the Russian mortality crisis. Addiction. 2011; 106:1957-1965. [PubMed: 21615584]

11. Ramstedt M. Population drinking and homicide in Australia: a time series analysis of the period 1950-2003. Drug Alcohol Rev. 2011; 30:466-472. [PubMed: 21896068] 
12. Vitiello B, Stoff DM. Subtypes of aggression and their relevance to child psychiatry. J Am Acad Child Adolesc Psychiatry. 1997; 36:307-315. [PubMed: 9055510]

13. Lesch KP, Merschdorf U. Impulsivity, aggression, and serotonin: a molecular psychobiological perspective. Behav Sci Law. 2000; 18:581-604. [PubMed: 11113963]

14. Kessler RC, Coccaro EF, Fava M, Jaeger S, Jin R, Walters E. The prevalence and correlates of DSM-IV intermittent explosive disorder in the National Comorbidity Survey Replication. Arch Gen Psychiatry. 2006; 63:669-678. [PubMed: 16754840]

15. Collins JJ, Messerschmidt PM. Epidemiology of alcohol-related violence. Alcohol Health Res World. 1993; 17:93-100.

16. Miczek KA, Fish EW, de Almeida RMM, Faccidomo S, DeBold JF. Role of alcohol consumption in escalation to violence. Ann N.Y. Acad Sci. 2004; 1036:278-289. [PubMed: 15817744]

17. Smith GS, Branas CC, Miller TR. Fatal nontraffic injuries involving alcohol: A metaanalysis. Ann Emerg Med. 1999; 33:659-668. [PubMed: 10339681]

18. Egami Y, Ford DE, Greenfield SF, Crum RM. Psychiatric profile and sociodemographic characteristics of adults who report physically abusing or neglecting children. Am. J Psychiatry. 1996; 153:921-928. [PubMed: 8659615]

19. Giancola, PR. Alcohol and Aggression: Theories and Mechanisms. In: McMurran, M., editor. Alcohol-Related Violence: Prevention and Treatment. Chichester: John Wiley \& Sons; 2013. p. 37-59.

20. Cortez, FCP.; Baltieri, DA. Alcohol-related violence: an international perspective. In: McMurran, M., editor. Alcohol-Related Violence: Prevention and Treatment. Chichester: John Wiley \& Sons; 2013. p. 19-33.

21. Gruenewald PJ, Remer L, Lipton R. Evaluating the alcohol environment: community geography and alcohol problems. Alcohol Res Health. 2002; 26:42-48. [PubMed: 12154650]

22. Gorman DM, Gruenewald PJ, Waller LA. Linking places to problems: Geospatial theories of neighborhoods, alcohol and crime. GeoJournal. 2013; 78:417-428. [PubMed: 23750067]

23. Tabakoff B, Hoffman PL. The neurobiology of alcohol consumption and alcoholism: an integrative history. Pharmacol Biochem Behav. 2013; 113:20-37. [PubMed: 24141171]

24. Mehta AK, Ticku MK. Ethanol potentiation of GABAergic transmission in cultured spinal cord neurons involves gamma-aminobutyric acidA-gated chloride channels. J Pharmacol Exp Ther. 1988; 246:558-564. [PubMed: 2457076]

25. Allan AM, Harris RA. $\gamma$-Aminobutyric acid and alcohol actions: Neurochemical studies of long sleep and short sleep mice. Life Sci. 1986; 39:2005-2015. [PubMed: 3784767]

26. Suzdak PD, Schwartz RD, Skolnick P, Paul SM. Ethanol stimulates $\gamma$-aminobutyric acid receptormediated chloride transport in rat brain synaptoneurosomes. Proc Natl Acad Sci U S A. 1986; 83:4071-4075. [PubMed: 2424017]

27. Ticku MK, Lowrimore P, Lehoullier P. Ethanol enhances GABA-induced 36Cl-influx in primary spinal cord cultured neurons. Brain Res Bull. 1986; 17:123-126. [PubMed: 3756540]

28. Baur R, Minier F, Sigel E. A GABA $A_{A}$ receptor of defined subunit composition and positioning: concatenation of five subunits. FEBS Lett. 2006; 580:1616-1620. [PubMed: 16494876]

29. Hanchar HJ, Wallner M, Olsen RW. Alcohol effects on $\gamma$-aminobutyric acid type A receptors: are extrasynaptic receptors the answer? Life Sci. 2004; 76:1-8. [PubMed: 15501475]

30. Wallner M, Hanchar HJ, Olsen RW. Ethanol enhances $\alpha_{4} \beta_{3} \delta$ and $\alpha_{6} \beta_{3} \delta \gamma$-aminobutyric acid type A receptors at low concentrations known to affect humans. Proc Natl Acad Sci U.S.A. 2003; 100:15218-15223. [PubMed: 14625373]

31. Borghese CM, Storustovu S, Ebert B, Herd MB, Belelli D, Lambert JJ, Marshall G, Wafford KA, Harris RA. The $\delta$ subunit of $\gamma$-aminobutyric acid type A receptors does not confer sensitivity to low concentrations of ethanol. J Pharmacol Exp Ther. 2006; 316:1360-1368. [PubMed: 16272217]

32. Hoffman PL, Rabe CS, Moses F, Tabakoff B. N-methyl-D-aspartate receptors and ethanol: inhibition of calcium flux and cyclic GMP production. J Neurochem. 1989; 52:1937-1940. [PubMed: 2542453]

33. Lima-Landman MT, Albuquerque EX. Ethanol potentiates and blocks NMDA-activated singlechannel currents in rat hippocampal pyramidal cells. FEBS Lett. 1989; 247:61-67. [PubMed: 2468533] 
34. Lovinger DM, White G, Weight FF. Ethanol inhibits NMDA-activated ion current in hippocampal neurons. Science. 1989; 243:1721-1724. [PubMed: 2467382]

35. Wright JM, Peoples RW, Weight FF. Single-channel and whole-cell analysis of ethanol inhibition of NMDA-activated currents in cultured mouse cortical and hippocampal neurons. Brain Res. 1996; 738:249-256. [PubMed: 8955520]

36. Nie Z, Madamba SG, Siggins GR. Ethanol inhibits glutamatergic neurotransmission in nucleus accumbens neurons by multiple mechanisms. J Pharmacol Exp Ther. 1994; 271:1566-1573. [PubMed: 7527857]

37. Roberto M, Schweitzer P, Madamba SG, Stouffer DG, Parsons LH, Siggins GR. Acute and chronic ethanol alter glutamatergic transmission in rat central amygdala: an in vitro and in vivo analysis. J Neurosci. 2004; 24:1594-1603. [PubMed: 14973247]

38. Ozawa S, Kamiya H, Tsuzuki K. Glutamate receptors in the mammalian central nervous system. Prog Neurobiol. 1998; 54:581-618. [PubMed: 9550192]

39. Traynelis SF, Wollmuth LP, McBain CJ, Menniti FS, Vance KM, Ogden KK, Hansen KB, Yuan H, Myers SJ, Dingledine R. Glutamate receptor ion channels: structure, regulation, and function. Pharmacol Rev. 2010; 62:405-496. [PubMed: 20716669]

40. Moriyoshi K, Masu M, Ishii T, Shigemoto R, Mizuno N, Nakanishi S. Molecular cloning and characterization of the rat NMDA receptor. Nature. 1991; 354:31-37. [PubMed: 1834949]

41. Kuner T, Schoepfer R, Korpi ER. Ethanol inhibits glutamate-induced currents in heteromeric NMDA receptor subtypes. NeuroReport. 1993; 5:297-300. [PubMed: 7905294]

42. Lovinger DM. Developmental decrease in ethanol inhibition of N-methyl-D-aspartate receptors in rat neocortical neurons: relation to the actions of ifenprodil. J Pharmacol Exp Ther. 1995; 274:164-172. [PubMed: 7616394]

43. Masood K, Wu C, Brauneis U, Weight FF. Differential ethanol sensitivity of recombinant Nmethyl-D-aspartate receptor subunits. Mol Pharmacol. 1994; 45:324-329. [PubMed: 8114679]

44. Mirshahi T, Woodward JJ. Ethanol sensitivity of heteromeric NMDA receptors: effects of subunit assembly, glycine and NMDAR1 $\mathrm{Mg}^{2+}$-insensitive mutants. Neuropharmacology. 1995; 34:347355. [PubMed: 7630488]

45. Smothers CT, Clayton R, Blevins T, Woodward JJ. Ethanol sensitivity of recombinant human Nmethyl-D-aspartate receptors. Neurochem Int. 2001; 38:333-340. [PubMed: 11137628]

46. Chu B, Anantharam V, Treistman SN. Ethanol inhibition of recombinant heteromeric NMDA channels in the presence and absence of modulators. J Neurochem. 1995; 65:140-148. [PubMed: 7540660]

47. Wills TA, Klug JR, Silberman Y, Baucum AJ, Weitlauf C, Colbran RJ, Delpire E, Winder DG. GluN2B subunit deletion reveals key role in acute and chronic ethanol sensitivity of glutamate synapses in bed nucleus of the stria terminalis. Proc Natl Acad Sci U.S.A. 2012; 109:E278-E287. [PubMed: 22219357]

48. Suvarna N, Borgland SL, Wang J, Phamluong K, Auberson YP, Bonci A, Ron D. Ethanol alters trafficking and functional N-methyl-D-aspartate receptor NR2 subunit ratio via H-Ras. J Biol Chem. 2005; 280:31450-31459. [PubMed: 16009711]

49. Brodie MS, Shefner SA, Dunwiddie TV. Ethanol increases the firing rate of dopamine neurons of the rat ventral tegmental area in vitro. Brain Res. 1990; 508:65-69. [PubMed: 2337793]

50. Brodie MS, Pesold C, Appel SB. Ethanol directly excites dopaminergic ventral tegmental area reward neurons. Alcohol Clin Exp Res. 1999; 23:1848-1852. [PubMed: 10591603]

51. DiChiara G, Imperato A. Drugs abused by humans preferentially increase synaptic dopamine concentrations in the mesolimbic system of freely moving rats. Proc Nat Acad Sci U.S.A. 1988; 85:5274-5278.

52. Budygin EA, Phillips PE, Robinson DL, Kennedy AP, Gainetdinov RR, Wightman RM. Effect of acute ethanol on striatal dopamine neurotransmission in ambulatory rats. J Pharmacol Exp Ther. 2001; 297:27-34. [PubMed: 11259524]

53. Aryal P, Dvir H, Choe S, Slesinger PA. A discrete alcohol pocket involved in GIRK channel activation. Nat Neurosci. 2009; 12:988-995. [PubMed: 19561601] 
54. Beckstead MJ, Phillips TJ. Mice selectively bred for high- or low-alcohol-induced locomotion exhibit differences in dopamine neuron function. J Pharmacol Exp Ther. 2009; 329:342-349. [PubMed: 19122113]

55. Ron D, Messing RO. Signaling pathways mediating alcohol effects. Curr Top Behav Neurosci. 2013; 13:87-126. [PubMed: 21877259]

56. Weiss F, Parsons LH, Schulteis G, Hyytia P, Lorang MT, Bloom FE, Koob GF. Ethanol selfadministration restores withdrawal-associated deficiencies in accumbal dopamine and 5hydroxytryptamine release in dependent rats. J Neurosci. 1996; 16:3474-3485. [PubMed: 8627380]

57. Yoshimoto K, McBride WJ, Lumeng L, Li TK. Alcohol stimulates the release of dopamine and serotonin in the nucleus accumbens. Alcohol. 1992; 9:17-22. [PubMed: 1370758]

58. Yoshimoto K, McBride WJ, Lumeng L, Li TK. Ethanol enhances the release of dopamine and serotonin in the nucleus accumbens of HAD and LAD lines of rats. Alcohol Clin Exp Res. 1992; 16:781-785. [PubMed: 1382391]

59. Yoshimoto K, McBride WJ. Regulation of nucleus accumbens dopamine release by the dorsal raphe nucleus in the rat. Neurochem Res. 1992; 17:401-407. [PubMed: 1356241]

60. Thielen RJ, Bare DJ, McBride WJ, Lumeng L, Li TK. Ethanol-stimulated serotonin release in the ventral hippocampus: an absence of rapid tolerance for the alcohol-preferring $\mathrm{P}$ rat and insensitivity in the alcohol-nonpreferring NP rat. Pharmacol Biochem Behav. 2002; 71:111-117. [PubMed: 11812514]

61. Lovinger DM. Ethanol potentiation of 5-HT 3 receptor-mediated ion current in NCB-20 neuroblastoma-cells. Neurosci Lett. 1991; 122:57-60. [PubMed: 1711659]

62. Lovinger DM, Zhou Q. Alcohols potentiate ion current mediated by recombinant 5-HT 3 RA receptors expressed in a mammalian cell line. Neuropharmacology. 1994; 33:1567-1572. [PubMed: 7760980]

63. Sellers EM, Higgins GA, Sobell MB. 5-HT and alcohol abuse. Trends Pharmacol Sci. 1992; 13:69. [PubMed: 1561716]

64. Sellers EM, Toneatto T, Romach MK, Somer GR, Sobell LC, Sobell MB. Clinical efficacy of the 5-HT 3 antagonist ondansetron in alcohol abuse and dependence. Alcohol Clin Exp Res. 1994; 18:879-885. [PubMed: 7978099]

65. Higley J, Hasert M, Suomi S, Linnoila M. The serotonin reuptake inhibitor sertraline reduces excessive alcohol consumption in nonhuman primates: Effect of stress. Neuropsychopharmacology. 1998; 18:431-443. [PubMed: 9571652]

66. Heinz A, Higley JD, Gorey JG, Saunders RC, Jones DW, Hommer D, Zajicek K, Suomi SJ, Lesch KP, Weinberger DR, Linnoila M. In vivo association between alcohol intoxication, aggression, and serotonin transporter availability in nonhuman primates. Am J Psychiatry. 1998; 155:1023-1028. [PubMed: 9699688]

67. Lovinger DM. 5- $\mathrm{HT}_{3}$ receptors and the neural actions of alcohols: an increasingly exciting topic. Neurochem Int. 1999; 35:125-130. [PubMed: 10405996]

68. Tikkanen R, Sjoberg RL, Ducci F, Goldman D, Holi M, Tiihonen J, Virkkunen M. Effects of MAOA-genotype, alcohol consumption, and aging on violent behavior. Alcohol Clin Exp Res. 2009; 33:428-434. [PubMed: 19120058]

69. Maguire EP, Mitchell EA, Greig SJ, Corteen N, Balfour DJ, Swinny JD, Lambert JJ, Belelli D. Extrasynaptic glycine receptors of rodent dorsal raphe serotonergic neurons: a sensitive target for ethanol. Neuropsychopharmacol. 2014; 39:1232-1244.

70. Lowery-Gionta EG, Marcinkiewcz CA, Kash TL. Functional alterations in the dorsal raphe nucleus following acute and chronic ethanol exposure. Neuropsychopharmacology. 2015; 40:590-600. [PubMed: 25120075]

71. Vasudeva RK, Hobby A, Kirby LG. Ethanol consumption in the Sprague-Dawley rat increases sensitivity of the dorsal raphe nucleus to 5,7-dihydroxytryptamine. Behav Brain Res. 2015 (epub ahead of print).

72. Hwa LS, Shimamoto A, Kayyali T, Norman KJ, Valentino RJ, DeBold JF, Miczek KA. Dissociation of $\mu$-opioid receptor and CRF-R1 antagonist effects on escalated ethanol consumption and mPFC serotonin in C57BL/6J mice. Addict Biol. 2014 (epub ahead of print). 
73. McClintick JN, McBride WJ, Bell RL, Ding ZM, Liu Y, Xuei X, Edenberg HJ. Gene expression changes in serotonin, $\mathrm{GABA}_{\mathrm{A}}$ receptors, neuropeptides and ion channels in the dorsal raphe nucleus of adolescent alcohol-preferring $(\mathrm{P})$ rats following binge-like alcohol drinking. Pharmacol Biochem Behav. 2015; 129:87-96. [PubMed: 25542586]

74. Bach H, Arango V, Kassir SA, Tsaava T, Dwork AJ, Mann JJ, Underwood MD. Alcoholics have more tryptophan hydroxylase $2 \mathrm{mRNA}$ and protein in the dorsal and median raphe nuclei. Alcohol Clin Exp Res. 2014; 38:1894-1901. [PubMed: 24942188]

75. Miczek, KA.; DeBold, JF.; Van Erp, AMM.; Tornatzky, W. Alcohol, GABA A-benzodiazepine receptor complex, and aggression. In: Galanter, M., editor. Recent Developments in Alcoholism. Alcoholism and Violence. New York: Plenum; 1997. p. 139-171.

76. Miczek KA, de Almeida RMM. Oral drug self-administration in the home cage of mice: alcoholheightened aggression and inhibition by the 5- $\mathrm{HT}_{1 \mathrm{~B}}$ agonist anpirtoline. Psychopharmacology. 2001; 157:421-429. [PubMed: 11605102]

77. Hwa LS, Nathanson AJ, Shimamoto A, Tayeh JK, Wilens AR, Holly EN, Newman EL, DeBold JF, Miczek KA. Aggression and increased glutamate in the mPFC during withdrawal from intermittent alcohol in outbred mice. Psychopharmacology. 2015 (epub ahead of print).

78. Pohorecky LA. Biphasic action of ethanol. Biobehav Rev. 1977; 1:231-240.

79. Cherek DR, Steinberg JL, Manno BR. Effects of alcohol on human aggressive behavior. J Stud Alcohol. 1985; 46:321-328. [PubMed: 4033132]

80. Miczek KA, Weerts EM, Tornatzky W, DeBold JF, Vatne TM. Alcohol and "bursts" of aggressive behavior: Ethological analysis of individual differences in rats. Psychopharmacology. 1992; 107:551-563. [PubMed: 1603899]

81. Miczek KA, Barros HM, Sakoda L, Weerts EM. Alcohol and heightened aggression in individual mice. Alcohol Clin Exp Res. 1998; 22:1698-1705. [PubMed: 9835283]

82. Weerts EM, Tornatzky W, Miczek KA. Prevention of the proaggressive effects of alcohol by benzodiazepine receptor antagonists in rats and in squirrel monkeys. Psychopharmacology. 1993; 111:144-152. [PubMed: 7870945]

83. Giancola PR, Zeichner A. The biphasic effects of alcohol on human physical aggression. J Abnorm Psychol. 1997; 106:598-607. [PubMed: 9358690]

84. de Almeida RMM, Rowlett JK, Cook JM, Yin W, Miczek KA. GABA $/$ /a1 receptor agonists and antagonists: effects on species-typical and heightened aggressive behavior after alcohol selfadministration in mice. Psychopharmacology. 2004; 172:255-263. [PubMed: 14647970]

85. Haller J, Kruk MR. Normal and abnormal aggression: human disorders and novel laboratory models. Neurosci Biobehav Rev. 2006; 30:292-303. [PubMed: 16483889]

86. Miczek KA, de Boer SF, Haller J. Excessive aggression as model of violence: a critical evaluation of current preclinical methods. Psychopharmacology. 2013; 226:445-458. [PubMed: 23430160]

87. Peterson JT, Pohorecky LA. Effect of chronic ethanol administration on intermale aggression in rats. Aggress Behav. 1989; 15:201-215.

88. Citrome L, Volavka J. Violent patients in the emergency setting. Psychiatr Clin North Am. 1999; 22:789-801. [PubMed: 10623971]

89. Jaffe JH, Babor TF, Fishbein DH. Alcoholics, aggression and antisocial personality. J Stud Alcohol. 1988; 1988:211-218. [PubMed: 3374134]

90. Mayfield D. Alcoholism, alcohol, intoxication and assaultive behavior. Dis Nerv Sys. 1976; 37:288-291.

91. Nicol AR, Gunn JC, Gristwood J, Foggitt RH, Watson JP. The relationship of alcoholism to violent behaviour resulting in long-term imprisonment. Brit J Psychiatry. 1973; 123:47-51. [PubMed: 4729874]

92. Schuckit MA, Russell JW. An evaluation of primary alcoholics with histories of violence. J Clin Psychiatry. 1984; 45:3-6. [PubMed: 6693360]

93. Miczek KA, Faccidomo S, de Almeida RMM, Bannai M, Fish EW, DeBold JF. Escalated aggressive behavior: new pharmacotherapeutic approaches and opportunities. Ann. N.Y. Acad. Sci. 2004; 1036:336-355. [PubMed: 15817748] 
94. Matsushita S, Kimura M, Miyakawa T, Yoshino A, Murayama M, Masaki T, Higuchi S. Association study of brain-derived neurotrophic factor gene polymorphism and alcoholism. Alcohol Clin Exp Res. 2004; 28:1609-1612. [PubMed: 15547445]

95. Nilsson KW, Sjoberg RL, Wargelius HL, Leppert J, Lindstrom L, Oreland L. The monoamine oxidase A (MAO-A) gene, family function and maltreatment as predictors of destructive behaviour during male adolescent alcohol consumption. Addiction. 2007; 102:389-398. [PubMed: 17298646]

96. Newman EL, Chu A, Bahamón B, Takahashi A, DeBold JF, Miczek KA. NMDA receptor antagonism: escalation of aggressive behavior in alcohol-drinking mice. Psychopharmacology. 2012; 224:167-177. [PubMed: 22588250]

97. Faccidomo S, Quadros IM, Takahashi A, Fish EW, Miczek KA. Infralimbic and dorsal raphé microinjection of the 5-HT $1 \mathrm{~B}$ receptor agonist CP-93,129: attenuation of aggressive behavior in CFW male mice. Psychopharmacology. 2012; 222:117-128. [PubMed: 22222863]

98. Takahashi A, Kwa C, DeBold JF, Miczek KA. GABA A receptors in the dorsal raphé nucleus of mice: escalation of aggression after alcohol consumption. Psychopharmacology. 2010; 211:467477. [PubMed: 20589493]

99. Chiavegatto S, Quadros IM, Ambar G, Miczek KA. Individual vulnerability to escalated aggressive behavior by a low dose of alcohol: decreased serotonin receptor mRNA in the prefrontal cortex of male mice. Genes Brain Behav. 2010; 9:110-119. [PubMed: 20002201]

100. de Almeida RM, Benini Q, Betat JS, Hipolide DC, Miczek KA, Svensson AI. Heightened aggression after chronic flunitrazepam in male rats: potential links to cortical and caudateputamen-binding sites. Psychopharmacology. 2008; 197:309-318. [PubMed: 18080114]

101. Fish EW, McKenzie-Quirk SD, Bannai M, Miczek KA. 5-HT 1 B receptor inhibition of alcoholheightened aggression in mice: comparison to drinking and running. Psychopharmacology. 2008; 197:145-156. [PubMed: 18071678]

102. de Almeida RMM, Nikulina EM, Faccidomo S, Fish EW, Miczek KA. Zolmitriptan--a 5-HT 1 B/D agonist, alcohol, and aggression in mice. Psychopharmacology. 2001; 157:131-141. [PubMed: 11594437]

103. Higley JD. Individual differences in alcohol-induced aggression. A nonhuman- primate model. Alcohol Res Health. 2001; 25:12-19. [PubMed: 11496962]

104. Heinz AJ, Beck A, Meyer-Lindenberg A, Sterzer P, Heinz A. Cognitive and neurobiological mechanisms of alcohol-related aggression. Nat Rev Neurosci. 2011; 12:400-413. [PubMed: 21633380]

105. Miczek KA, Barry H III. Effects of alcohol on attack and defensive-submissive reactions in rats. Psychopharmacology. 1977; 52:231-237. [PubMed: 406625]

106. Miczek KA, Winslow JT, DeBold JF. Heightened aggressive behavior by animals interacting with alcohol-treated conspecifics: Studies with mice, rats and squirrel monkeys. Pharmacol Biochem Behav. 1984; 20:349-353. [PubMed: 6538687]

107. Yoshimura H, Ogawa N. [Pharmaco-ethological analysis of agonistic behavior between resident and intruder mice: effects of ethylalcohol.]. Nihon Yakurigaku Zasshi. 1983; 81:135-141. [PubMed: 6682824]

108. Sinha R. How does stress increase risk of drug abuse and relapse? Psychopharmacology. 2001; 158:343-359. [PubMed: 11797055]

109. Brady KT, Sonne SC. The role of stress in alcohol use, alcoholism treatment, and relapse. Alcohol Res Health. 1999; 23:263-271. [PubMed: 10890823]

110. Pohorecky LA. The interaction of alcohol and stress, a review. Neurosci Biobehav Rev. 1981; 5:209-229. [PubMed: 6115346]

111. Pohorecky LA. Stress and alcohol interaction: an update of human research. Alc Clin Exp Res. $1991 ; 15: 438-459$.

112. Becker HC, Lopez MF, Doremus-Fitzwater TL. Effects of stress on alcohol drinking: a review of animal studies. Psychopharmacology. 2011; 218:131-156. [PubMed: 21850445]

113. Noori HR, Helinski S, Spanagel R. Cluster and meta-analyses on factors influencing stressinduced alcohol drinking and relapse in rodents. Addict Biol. 2014; 19:225-232. [PubMed: 24589296] 
114. Miczek KA, Yap JJ, Covington HE III. Social stress, therapeutics and drug abuse: preclinical models of escalated and depressed intake. Pharmacol Ther. 2008; 120:102-128. [PubMed: 18789966]

115. McKenzie-Quirk SD, Miczek KA. Social rank and social separation as determinants of alcohol drinking in squirrel monkeys. Psychopharmacology. 2008; 201:137-145. [PubMed: 18641974]

116. Helms CM, McClintick MN, Grant KA. Social rank, chronic ethanol self-administration, and diurnal pituitary-adrenal activity in cynomolgus monkeys. Psychopharmacology. 2012; 224:133143. [PubMed: 22526537]

117. Kudryavtseva NN, Bakshtanovskaya IV, Koryakina LA. Social model of depression in mice of C57BL/6J strain. Pharmacol Biochem Behav. 1991; 38:315-320. [PubMed: 2057501]

118. Peters S, Slattery DA, Flor PJ, Neumann ID, Reber SO. Differential effects of baclofen and oxytocin on the increased ethanol consumption following chronic psychosocial stress in mice. Addict Biol. 2013; 18:66-77. [PubMed: 23126471]

119. Sillaber I, Rammes G, Zimmermann S, Mahal B, Zieglgansberger W, Wurst W, Holsboer F, Spanagel R. Enhanced and delayed stress-induced alcohol drinking in mice lacking functional CRH1 receptors. Science. 2002; 296:931-933. [PubMed: 11988580]

120. Norman KJ, Seiden JA, Klickstein JA, Han X, Hwa LS, DeBold JF, Miczek KA. Social stress and escalated drug self-administration in mice I. Alcohol and corticosterone. Psychopharmacology. 2015; 232:991-1001. [PubMed: 25242256]

121. Molander A, Vengeliene V, Heilig M, Wurst W, Deussing JM, Spanagel R. Brain-specific inactivation of the Crhr1 gene inhibits post-dependent and stress-induced alcohol intake, but does not affect relapse-like drinking. Neuropsychopharmacology. 2012; 37:1047-1056. [PubMed: 22113086]

122. Riga D, Schmitz LJ, Van der Harst JE, van MY, Hoogendijk WJ, Smit AB, De Vries TJ, Spijker S. A sustained depressive state promotes a guanfacine reversible susceptibility to alcohol seeking in rats. Neuropsychopharmacology. 2014; 39:1115-1124. [PubMed: 24192553]

123. Scott, JP. Aggression. Chicago: University of Chicago Press; 1958.

124. Fish EW, DeBold JF, Miczek KA. Aggressive behavior as a reinforcer in mice: Activation by allopregnanolone. Psychopharmacology. 2002; 163:459-466. [PubMed: 12373446]

125. Hsu Y, Earley RL, Wolf LL. Modulation of aggressive behaviour by fighting experience: mechanisms and contest outcomes. Biol Rev Camb Philos Soc. 2006; 81:33-74. [PubMed: 16460581]

126. Nelson RJ, Trainor BC. Neural mechanisms of aggression. Nat Neurosci Rev. 2007; 8:536-546.

127. Caramaschi D, de Boer SF, de Vries H, Koolhaas JM. Development of violence in mice through repeated victory along with changes in prefrontal cortex neurochemistry. Behav Brain Res. 2008; 189:263-272. [PubMed: 18281105]

128. Couppis $\mathrm{MH}$, Kennedy $\mathrm{CH}$. The rewarding effect of aggression is reduced by nucleus accumbens dopamine receptor antagonism in mice. Psychopharmacology. 2008; 197:449-456. [PubMed: 18193405]

129. Rassnick S, Pulvirenti L, Koob GF. Oral ethanol self-administration in rats is reduced by the administration of dopamine and glutamate receptor antagonists into the nucleus accumbens. Psychopharmacology. 1992; 109:92-98. [PubMed: 1365677]

130. Weiss F, Lorang MT, Bloom FE, Koob GF. Oral alcohol self-administration stimulates dopamine release in the rat nucleus accumbens - Genetic and motivational determinants. J Pharmacol Exp Ther. 1993; 267:250-258. [PubMed: 8229752]

131. Koob GF, Roberts AJ, Schulteis G, Parsons LH, Heyser CJ, Hyytia P, Merlo-Pich E, Weiss F. Neurocircuitry targets in ethanol reward and dependence. Alcohol Clin Exp Res. 1998; 22:3-9. [PubMed: 9514280]

132. Heilig M, Egli M. Pharmacological treatment of alcohol dependence: target symptoms and target mechanisms. Pharmacol Ther. 2006; 111:855-876. [PubMed: 16545872]

133. Barr CS, Newman TK, Lindell S, Becker ML, Shannon C, Champoux M, Suomi SJ, Higley JD. Early experience and sex interact to influence limbic-hypothalamic-pituitary-adrenal-axis function after acute alcohol administration in rhesus macaques (Macaca mulatta). Alcohol Clin Exp Res. 2004; 28:1114-1119. [PubMed: 15252299] 
134. Rodd ZA, Bell RL, Melendez RI, Kuc KA, Lumeng L, Li TK, Murphy JM, McBride WJ. Comparison of intracranial self-administration of ethanol within the posterior ventral tegmental area between alcohol-preferring and Wistar rats. Alcohol Clin Exp Res. 2004; 28:1212-1219. [PubMed: 15318120]

135. Spanagel R, Weiss F. The dopamine hypothesis of reward: past and current status. Trends Neurosci. 1999; 22:521-527. [PubMed: 10529820]

136. Heilig M, Koob GF. A key role for corticotropin-releasing factor in alcohol dependence. Trends Neurosci. 2007; 30:399-406. [PubMed: 17629579]

137. Fish EW, De Bold JF, Miczek KA. Escalated aggression as a reward: Corticosterone and GABA receptor positive modulators in mice. Psychopharmacology. 2005; 182:116-127. [PubMed: 16133129]

138. van Erp AM, Miczek KA. Increased accumbal dopamine during daily alcohol consumption and subsequent aggressive behavior in rats. Psychopharmacology. 2007; 191:679-688. [PubMed: 17136400]

139. de Boer SF, Caramaschi D, Natarajan D, Koolhaas JM. The vicious cycle towards violence: focus on the negative feedback mechanisms of brain serotonin neurotransmission. Front Behav Neurosci. 2009; 3:52. [PubMed: 19949469]

140. de Boer SF, Koolhaas JM. 5- $\mathrm{HT}_{1 \mathrm{~A}}$ and 5-HT $1 \mathrm{~B}$ receptor agonists and aggression: A pharmacological challenge of the serotonin deficiency hypothesis. Eur J Pharmacol. 2005; 526:125-139. [PubMed: 16310183]

141. Van Der Vegt BJ, Lieuwes N, van de Wall EH, Kato K, Moya-Albiol L, Martinez-Sanchis S, de Boer SF, Koolhaas JM. Activation of serotonergic neurotransmission during the performance of aggressive behavior in rats. Behav Neurosci. 2003; 117:667-674. [PubMed: 12931952]

142. Kravitz EA, Huber R. Aggression in invertebrates. Curr Opin Neurobiol. 2003; 13:736-743. [PubMed: 14662376]

143. Summers CH, Korzan WJ, Lukkes JL, Watt MJ, Forster GL, Overli O, Hoglund E, Larson ET, Ronan PJ, Matter JM, Summers TR, Renner KJ, Greenberg N. Does serotonin influence aggression? Comparing regional activity before and during social interaction. Physiol Biochem Zool. 2005; 78:679-694. [PubMed: 16059845]

144. Miczek KA, de Almeida RMM, Kravitz EA, Rissman EF, de Boer SF, Raine A. Neurobiology of escalated aggression and violence. J Neurosci. 2007; 27:11803-11806. [PubMed: 17978016]

145. Virkkunen M, Linnoila M. Brain serotonin, Type II alcoholism and impulsive violence. J Stud Alcohol. 1993; (Supplement 11):163-169.

146. Virkkunen M, Kallio E, Rawlings R, Tokola R, Poland RE, Guidotti A, Nemeroff C, Bissette G, Kalogeras K, Karonen SL, Linnoila M. Personality profiles and state aggressiveness in Finnish alcoholic, violent offenders, fire setters, and healthy volunteers. Arch Gen Psychiatry. 1994; 51:28-33. [PubMed: 7506516]

147. Virkkunen M, Goldman D, Nielsen DA, Linnoila M. Low brain serotonin turnover rate (low CSF 5-HIAA) and impulsive violence. J Psychiatry Neurosci. 1995; 20:271-275. [PubMed: 7544158]

148. Beck A, Heinz AJ, Heinz A. Translational clinical neuroscience perspectives on the cognitive and neurobiological mechanisms underlying alcohol-related aggression. Curr Top Behav Neurosci. 2014; 17:443-474. [PubMed: 24338662]

149. Brodie BB, Shore PA. A concept for a role of serotonin and norepinephrine as chemical mediators in the brain. Analgesia. 1957; 66:631-642.

150. Giacalone E, Tansella M, Valzelli L, Garattini S. Brain serotonin metabolism in isolated aggressive mice. Biochem Pharmacol. 1968; 17:1315-1327. [PubMed: 5690693]

151. Olivier B. Serotonin and aggression. Ann N Y Acad Sci. 2004; 1036:382-392. [PubMed: 15817750]

152. Takahashi A, Quadros IM, de Almeida RM, Miczek KA. Brain serotonin receptors and transporters: initiation vs. termination of escalated aggression. Psychopharmacology. 2011; 213:183-212. [PubMed: 20938650]

153. Morrison TR, Melloni RH Jr. The role of serotonin, vasopressin, and serotonin/vasopressin interactions in aggressive behavior. Curr Top Behav Neurosci. 2014; 17:189-228. [PubMed: 24496652] 
154. Lesch KP, Bengel D, Heils A, Sabol SZ, Greenberg BD, Petri S, Benjamin J, Mueller CR, Hamer $\mathrm{DH}$, Murphy DL. Association of anxiety-related traits with a polymorphism in the serotonin transporter gene regulatory region. Science. 1996; 264:1537-1551.

155. Schwandt ML, Lindell SG, Sjoberg RL, Chisholm KL, Higley JD, Suomi SJ, Heilig M, Barr CS. Gene-environment interactions and response to social intrusion in male and female rhesus macaques. Biol Psychiatry. 2010; 67:323-330. [PubMed: 20015482]

156. de Almeida RMM, Ferrari PF, Parmigiani S, Miczek KA. Escalated aggressive behavior: Dopamine, serotonin and GABA. Eur J Pharmacol. 2005; 526:51-64. [PubMed: 16325649]

157. de Almeida RM, Rosa MM, Santos DM, Saft DM, Benini Q, Miczek KA. 5-HT 1 B receptors, ventral orbitofrontal cortex, and aggressive behavior in mice. Psychopharmacology. 2006; 185:441-450. [PubMed: 16550387]

158. de Almeida RMM, Miczek KA. Aggression escalated by social instigation or by discontinuation of reinforcement ("frustration") in mice: inhibition by anpirtoline, a 5-HT $1 \mathrm{~B}$ receptor agonist. Neuropsychopharmacology. 2002; 27:171-181. [PubMed: 12093591]

159. Gowin JL, Swann AC, Moeller FG, Lane SD. Zolmitriptan and human aggression: interaction with alcohol. Psychopharmacology. 2010; 210:521-531. [PubMed: 20407761]

160. Coccaro EF, McCloskey MS, Fitzgerald DA, Phan KL. Amygdala and orbitofrontal reactivity to social threat in individuals with impulsive aggression. Biol Psychiatry. 2007; 62:168-178. [PubMed: 17210136]

161. Sterzer P, Stadler C, Krebs A, Kleinschmidt A, Poustka F. Abnormal neural responses to emotional visual stimuli in adolescents with conduct disorder. Biol Psychiatry. 2005; 57:7-15. [PubMed: 15607294]

162. Lee TM, Chan SC, Raine A. Strong limbic and weak frontal activation to aggressive stimuli in spouse abusers. Mol Psychiatry. 2008; 13:655-656. [PubMed: 18560435]

163. Kollack-Walker S, Newman SW. Mating and agonistic behavior produce different patterns of Fos immunolabeling in the male Syrian hamster brain. Neuroscience. 1995; 66:721-736. [PubMed: 7644033]

164. Lee H, Kim DW, Remedios R, Anthony TE, Chang A, Madisen L, Zeng H, Anderson DJ. Scalable control of mounting and attack by Esr1+ neurons in the ventromedial hypothalamus. Nature. 2014; 509:627-632. [PubMed: 24739975]

165. Lin D, Boyle MP, Dollar P, Lee H, Lein ES, Perona P, Anderson DJ. Functional identification of an aggression locus in the mouse hypothalamus. Nature. 2011; 470:221-226. [PubMed: 21307935]

166. Bannai M, Fish EW, Faccidomo S, Miczek KA. Anti-aggressive effects of agonists at 5-HT $1 \mathrm{~B}$ receptors in the dorsal raphe nucleus of mice. Psychopharmacology. 2007; 193:295-304. [PubMed: 17440711]

167. Faccidomo S, Bannai M, Miczek KA. Escalated aggression after alcohol drinking in male mice: dorsal raphe and prefrontal cortex serotonin and 5- $\mathrm{HT}_{1 \mathrm{~B}}$ receptors. Neuropsychopharmacology. 2008; 33:2888-2899. [PubMed: 18305458]

168. Mhatre MC, Pena G, Sieghart W, Ticku MK. Antibodies specific for GABAA receptor a subunits reveal that chronic alcohol treatment down-regulates a-subunit expression in rat brain regions. $\mathrm{J}$ Neurochem. 1993; 61:1620-1625. [PubMed: 8228981]

169. Matthews DB, Devaud LL, Fritschy JM, Sieghart W, Morrow AL. Differential regulation of $\mathrm{GABA}_{\mathrm{A}}$ receptor gene expression by ethanol in the rat hippocampus versus cerebral cortex. $\mathrm{J}$ Neurochem. 1998; 70:1160-1166. [PubMed: 9489737]

170. Follesa P, Biggio F, Talani G, Murru L, Serra M, Sanna E, Biggio G. Neurosteroids, GABA A receptors, and ethanol dependence. Psychopharmacology. 2006; 186:267-280. [PubMed: 16163526]

171. Mahmoudi M, Kang MH, Tillakaratne N, Tobin AJ, Olsen RW. Chronic intermittent ethanol treatment in rats increases $\mathrm{GABA}_{\mathrm{A}}$ receptor a4-subunit expression: possible relevance to alcohol dependence. J Neurochem. 1997; 68:2485-2492. [PubMed: 9166743]

172. Miczek KA, DeBold JF, Van Erp AMM. Neuropharmacological characteristics of individual differences in alcohol effects on aggression in rodents and primates. Behav Pharmacol. 1994; 5:407-421. [PubMed: 11224293] 
173. DiMascio A. The effects of benzodiazepines on aggression: reduced or increased? Psychopharmacologia. 1973; 30:95-102. [PubMed: 4576033]

174. Albrecht B, Staiger PK, Hall K, Miller P, Best D, Lubman DI. Benzodiazepine use and aggressive behaviour: a systematic review. Aust N Z J Psychiatry. 2014; 48:1096-1114. [PubMed: 25183003]

175. Jonas JM, Coleman BS, Sheridan AQ, Kalinske RW. Comparative clinical profiles of triazolam versus other shorter-acting hypnotics. J Clin Psychiatry. 1992; 53(Suppl):19-31. [PubMed: 1336776]

176. Pilowsky LS, Ring H, Shine PJ, Battersby M, Lader M. Rapid tranquillisation. A survey of emergency prescribing in a general psychiatric hospital. Br J Psychiatry. 1992; 160:831-835. [PubMed: 1352166]

177. Fulde G, Preisz P. Managing aggressive and violent patients. Aust Prescr. 2011; 34:115-118.

178. Angelotti TP, Macdonald RL. Assembly of GABA A receptor subunits: $\alpha_{1}-\beta_{1}$ and $\alpha_{1}-\beta_{1}-\gamma_{2} S$ subunits produce unique ion channels with dissimilar single-channel properties. J Neurosci. 1993; 13:1429-1440. [PubMed: 7681870]

179. Pritchett DB, Sontheimer H, Shivers BD, Ymer S, Kettenmann H, Schofield PR, Seeburg PH. Importance of a novel GABA $\mathrm{A}_{\mathrm{A}}$ receptor subunit for benzodiazepine pharmacology. Nature. 1989; 338:582-585. [PubMed: 2538761]

180. Günther U, Benson J, Benke D, Fritschy JM, Reyes G, Knoflach F, Crestani F, Aguzzi A, Arigoni M, Lang Y, et al. Benzodiazepine-insensitive mice generated by targeted disruption of the $\gamma_{2}$ subunit gene of $\gamma$-aminobutyric acid type A receptors. Proc Natl Acad Sci U S A. 1995; 92:77497753. [PubMed: 7644489]

181. Tan KR, Rudolph U, Luscher C. Hooked on benzodiazepines: GABA $\mathrm{A}$ receptor subtypes and addiction. Trends Neurosci. 2011; 34:188-197. [PubMed: 21353710]

182. Newman EL, Smith KS, Takahashi A, Chu A, Hwa LS, Chen Y, DeBold JF, Rudolph U, Miczek KA. a2-containing GABA(A) receptors: a requirement for midazolam-escalated aggression and social approach in mice. Psychopharmacology. 2015 In press.

183. Puglisi-Allegra S, Mandel P. Effects of sodium n-dipropylacetate, muscimol hydrobromide and (R,S)nipecotic acid amide on isolation-induced aggressive behavior in mice.

Psychopharmacology. 1980; 70:287-290. [PubMed: 6777802]

184. Puglisi-Allegra S, Simler S, Kempf E, Mandel P. Involvement of the GABAergic system on shock-induced aggressive behavior in two strains of mice. Pharmacol Biochem Behav. 1981; 14(S1):13-18. [PubMed: 6787619]

185. Rodgers RJ, Depaulis A. Gabaergic influences on defensive fighting in rats. Pharmacol Biochem Behav. 1982; 17:451-456. [PubMed: 6815666]

186. Allikmets LH, Rago LK. The action of benzodiazepine antagonist Ro 15-1788 on the effects of GABA-ergic drugs. Naunyn Schmiedebergs Arch Pharmacol. 1983; 324:235-237. [PubMed: 6318128]

187. Takahashi A, Shimamoto A, Boyson CO, DeBold JF, Miczek KA. GABA B receptor modulation of serotonin neurons in the dorsal raphe nucleus and escalation of aggression in mice. $J$ Neurosci. 2010; 30:11771-11780. [PubMed: 20810897]

188. Majewska MD, Harrison NL, Schwartz RD, Barker JL, Paul SM. Steroid hormone metabolites are barbiturate-like modulators of the GABA receptor. Science. 1986; 232:1004-1007. [PubMed: 2422758]

189. Gee KW, Chang WC, Brinton RE, McEwen BS. GABA-dependent modulation of the Clionophore by steroids in rat brain. Eur J Pharmacol. 1987; 136:419-423. [PubMed: 3609126]

190. Baulieu EE, Robel P. Neurosteroids: a new brain function? J Steroid Biochem Mol Biol. 1990; 37:395-403. [PubMed: 2257243]

191. Akwa Y, Young J, Kabbadj K, Sancho MJ, Zucman D, Vourc'H C, Jung-Testas I, Hu ZY, Le G, Jo DH, Corpechot C, Simon P, Baulieu EE, Robel P. Neurosteroids: biosynthesis, metabolism and function of pregnenolone and dehydroepiandrosterone in the brain. J Steroid Biochem Mol Biol. 1991; 40:71-81. [PubMed: 1835645]

192. Baulieu EE. Neurosteroids: An overview. Adv Biochem Psychopharmacol. 1992; 47:1-16. [PubMed: 1354912] 
193. Lambert JL, Belilli D, Hill-Venning C, Peters JA. Neurosteroids and GABA $\mathrm{A}_{\mathrm{A}}$ receptor function. TrendsPharmacol Sci. 1995; 16:295-303.

194. Schüle C, Nothdurfter C, Rupprecht R. The role of allopregnanolone in depression and anxiety. Prog Neurobiol. 2014; 113:79-87. [PubMed: 24215796]

195. VanDoren MJ, Matthews DB, Janis GC, Grobin AC, Devaud LL, Morrow AL. Neuroactive steroid 3a-hydroxy-5a-pregnane-20-one modulates electrophysiological and behavioral actions of ethanol. J Neurosci. 2000; 20:1982-1989. [PubMed: 10684899]

196. Morrow AL, Janis GC, VanDoren MJ, Matthews DB, Samson HH, Janak PH, Grant KA. Neurosteroids mediate pharmacological effects of ethanol: A new mechanism of ethanol action? Alcohol Clin Exp Res. 1999; 23:1933-1940. [PubMed: 10630613]

197. Purdy RH, Morrow AL, Moore PH, Paul SM. Stress-induced elevations of $\gamma$-aminobutyric acid type A receptor-active steroids in the rat brain. Proc Natl Acad Sci U.S.A. 1991; 88:4553-4557. [PubMed: 1852011]

198. Pinna G, Costa E, Guidotti A. Changes in brain testosterone and allopregnanolone biosynthesis elicit aggressive behavior. Proc Natl Acad Sci U.S.A. 2005; 102:2135-2140. [PubMed: 15677716]

199. Nelson M, Pinna G. S-norfluoxetine microinfused into the basolateral amygdala increases allopregnanolone levels and reduces aggression in socially isolated mice. Neuropharmacology. 2011; 60:1154-1159. [PubMed: 20971127]

200. Fish EW, Faccidomo S, DeBold JF, Miczek KA. Alcohol, allopregnanolone and aggression in mice. Psychopharmacology. 2001; 153:473-483. [PubMed: 11243495]

201. Guidotti A, Dong E, Matsumoto K, Pinna G, Rasmusson AM, Costa E. The socially-isolated mouse: a model to study the putative role of allopregnanolone and 5a-dihydroprogesterone in psychiatric disorders. Brain Res Rev. 2001; 37:110-115. [PubMed: 11744079]

202. Biggio G, Pisu MG, Biggio F, Serra M. Allopregnanolone modulation of HPA axis function in the adult rat. Psychopharmacology. 2014; 231:3437-3444. [PubMed: 24658404]

203. Addolorato G, Leggio L, Abenavoli L, Agabio R, Caputo F, Capristo E, Colombo G, Gessa GL, Gasbarrini G. Baclofen in the treatment of alcohol withdrawal syndrome: a comparative study vs diazepam. Am J Med. 2006; 119:276-278. [PubMed: 16490478]

204. Brennan JL, Leung JG, Gagliardi JP, Rivelli SK, Muzyk AJ. Clinical effectiveness of baclofen for the treatment of alcohol dependence: a review. Clin Pharmacol. 2013; 5:99-107. [PubMed: 23869179]

205. Ponizovsky AM, Rosca P, Aronovich E, Weizman A, Grinshpoon A. Baclofen as add-on to standard psychosocial treatment for alcohol dependence: a randomized, double-blind, placebocontrolled trial with 1-year follow-up. J Subst Abuse Treat. 2014; 52:24-30. [PubMed: 25572706]

206. Bucknam W. Suppression of symptoms of alcohol dependence and craving using high-dose baclofen. Alcohol Alcohol. 2007; 42:158-160. [PubMed: 17172256]

207. Addolorato G, Caputo F, Capristo E, Domenicali M, Bernardi M, Janiri L, Agabio R, Colombo G, Gessa GL, Gasbarrini G. Baclofen efficacy in reducing alcohol craving and intake: a preliminary double-blind randomized controlled study. Alcohol Alcohol. 2002; 37:504-508. [PubMed: 12217947]

208. File SE, Zharkovsky A, Gulati K. Effects of baclofen and nitrendipine on ethanol withdrawal responses in the rat. Neuropharmacology. 1991; 30:183-190. [PubMed: 2030822]

209. Rudissaar R, Pruus K, Skrebuhhova-Malmros T, Allikmets L, Matto V. Involvement of GABAergic neurotransmission in the neurobiology of the apomorphine-induced aggressive behavior paradigm, a model of psychotic behavior in rats. Methods Find Exp Clin Pharmacol. 2000; 22:637-640. [PubMed: 11256236]

210. Takahashi A, Schilit AN, Kim J, DeBold JF, Koide T, Miczek KA. Behavioral characterization of escalated aggression induced by $\mathrm{GABA}_{\mathrm{B}}$ receptor activation in the dorsal raphe nucleus. Psychopharmacology. 2012; 224:155-166. [PubMed: 22395428]

211. Gruol DL, Parsons KL, DiJulio N. Acute ethanol alters calcium signals elicited by glutamate receptor agonists and K+ depolarization in cultured cerebellar Purkinje neurons. Brain Res. 1997; 773:82-89. [PubMed: 9409708] 
212. Hassanain M, Bhatt S, Siegel A. Differential modulation of feline defensive rage behavior in the medial hypothalamus by 5-HT $1 \mathrm{~A}$ and 5-HT⿰ $\mathrm{H}_{2}$ receptors. Brain Res. 2003; 981:201-209. [PubMed: 12885442]

213. Fernandes C, Paya-Cano JL, Sluyter F, D’Souza U, Plomin R, Schalkwyk LC. Hippocampal gene expression profiling across eight mouse inbred strains: towards understanding the molecular basis for behaviour. Eur J Neurosci. 2004; 19:2576-2582. [PubMed: 15128411]

214. Schubert K, Shaikh MB, Han Y, Pohorecky L, Siegel A. Differential effects of ethanol on feline rage and predatory attack behavior: an underlying neural mechanism. Alcohol Clin Exp Res. 1996; 20:882-889. [PubMed: 8865964]

215. Enoch MA, Rosser AA, Zhou Z, Mash DC, Yuan Q, Goldman D. Expression of glutamatergic genes in healthy humans across 16 brain regions; altered expression in the hippocampus after chronic exposure to alcohol or cocaine. Genes Brain Behav. 2014; 13:758-768. [PubMed: 25262781]

216. Jin Z, Bhandage AK, Bazov I, Kononenko O, Bakalkin G, Korpi ER, Birnir B. Selective increases of AMPA, NMDA, and kainate receptor subunit mRNAs in the hippocampus and orbitofrontal cortex but not in prefrontal cortex of human alcoholics. Front Cell Neurosci. 2014; 8:11. [PubMed: 24523671]

217. Cacciaglia R, Nees F, Pohlack ST, Ruttorf M, Winkelmann T, Witt SH, Nieratschker V, Rietschel $\mathrm{M}$, Flor H. A risk variant for alcoholism in the NMDA receptor affects amygdala activity during fear conditioning in humans. Biol Psychol. 2013; 94:74-81. [PubMed: 23693003]

218. Domart MC, Benyamina A, Lemoine A, Bourgain C, Blecha L, Debuire B, Reynaud M, Saffroy R. Association between a polymorphism in the promoter of a glutamate receptor subunit gene (GRIN2A) and alcoholism. Addict Biol. 2012; 17:783-785. [PubMed: 21507155]

219. Karpyak VM, Biernacka JM, Geske JR, Jenkins GD, Cunningham JM, Ruegg J, Kononenko O, Leontovich AA, Abulseoud OA, Hall-Flavin DK, Loukianova LL, Schneekloth TD, Skime MK, Frank J, Nothen MM, Rietschel M, Kiefer F, Mann KF, Weinshilboum RM, Frye MA, Choi DS. Genetic markers associated with abstinence length in alcohol-dependent subjects treated with acamprosate. Transl Psychiatry. 2014; 4:e462. [PubMed: 25290263]

220. Du X, Elberger AJ, Matthews DB, Hamre KM. Heterozygous deletion of NR1 subunit of the NMDA receptor alters ethanol-related behaviors and regional expression of NR2 subunits in the brain. Neurotoxicol Teratol. 2012; 34:177-186. [PubMed: 21945132]

221. Duncan GE, Moy SS, Perez A, Eddy DM, Zinzow WM, Lieberman JA, Snouwaert JN, Koller $\mathrm{BH}$. Deficits in sensorimotor gating and tests of social behavior in a genetic model of reduced NMDA receptor function. Behav Brain Res. 2004; 153:507-519. [PubMed: 15265649]

222. Rammes G, Mahal B, Putzke J, Parsons C, Spielmanns P, Pestel E, Spanagel R, Zieglgansberger W, Schadrack J. The anti-craving compound acamprosate acts as a weak NMDA-receptor antagonist, but modulates NMDA-receptor subunit expression similar to memantine and MK-801. Neuropharmacology. 2001; 40:749-760. [PubMed: 11369029]

223. Hölter SM, Linthorst AC, Reul JM, Spanagel R. Withdrawal symptoms in a long-term model of voluntary alcohol drinking in Wistar rats. Pharmacol Biochem Behav. 2000; 66:143-151. [PubMed: 10837854]

224. Morales M, Varlinskaya EI, Spear LP. Low doses of the NMDA receptor antagonists, MK-801, PEAQX, and ifenprodil, induces social facilitation in adolescent male rats. Behav Brain Res. 2013; 250:18-22. [PubMed: 23651880]

225. Krystal JH, Petrakis IL, Limoncelli D, Webb E, Gueorgueva R, D’Souza DC, Boutros NN, Trevisan L, Charney DS. Altered NMDA glutamate receptor antagonist response in recovering ethanol-dependent patients. Neuropsychopharmacology. 2003; 28:2020-2028. [PubMed: 12888778]

226. Krupitsky EM, Neznanova O, Masalov D, Burakov AM, Didenko T, Romanova T, Tsoy M, Bespalov A, Slavina TY, Grinenko AA, Petrakis IL, Pittman B, Gueorguieva R, Zvartau EE, Krystal JH. Effect of memantine on cue-induced alcohol craving in recovering alcohol-dependent patients. Am J Psychiatry. 2007; 164:519-523. [PubMed: 17329479]

227. Krystal JH, Staley J, Mason G, Petrakis IL, Kaufman J, Harris RA, Gelernter J, Lappalainen J. Gamma-aminobutyric acid type A receptors and alcoholism: intoxication, dependence, vulnerability, and treatment. Arch Gen Psychiatry. 2006; 63:957-968. [PubMed: 16952998] 
228. Allgaier C. Ethanol sensitivity of NMDA receptors. Neurochem Int. 2002; 41:377-382. [PubMed: 12213224]

229. Wenzel A, Scheurer L, Künzi R, Fritschy JM, Mohler H, Benke D. Distribution of NMDA receptor subunit proteins NR2A, 2B, 2C and 2D in rat brain. NeuroReport. 1995; 7:45-48. [PubMed: 8742413]

230. Halasz J, Toth M, Kallo I, Liposits Z, Haller J. The activation of prefrontal cortical neurons in aggression--a double labeling study. Behav Brain Res. 2006; 175:166-175. [PubMed: 16978716]

231. Takahashi A, Nagayasu K, Nishitani N, Kaneko S, Koide T. Control of intermale aggression by medial prefrontal cortex activation in the mouse. PLoS. One. 2014; 9:e94657. [PubMed: 24740241]

232. Lau CG, Zukin RS. NMDA receptor trafficking in synaptic plasticity and neuropsychiatric disorders. Nat Rev Neurosci. 2007; 8:413-426. [PubMed: 17514195]

233. Ciccocioppo R, Gehlert DR, Ryabinin A, Kaur S, Cippitelli A, Thorsell A, Le AD, Hipskind PA, Hamdouchi C, Lu J, Hembre EJ, Cramer J, Song M, McKinzie D, Morin M, Economidou D, Stopponi S, Cannella N, Braconi S, Kallupi M, de GG, Massi M, George DT, Gilman J, Hersh J, Tauscher JT, Hunt SP, Hommer D, Heilig M. Stress-related neuropeptides and alcoholism: CRH, NPY, and beyond. Alcohol. 2009; 43:491-498. [PubMed: 19913192]

234. Heinrichs M, von DB, Domes G. Oxytocin, vasopressin, and human social behavior. Front Neuroendocrinol. 2009; 30:548-557. [PubMed: 19505497]

235. Bielsky IF, Young LJ. Oxytocin, vasopressin, and social recognition in mammals. Peptides. 2004; 25:1565-1574. [PubMed: 15374658]

236. De Felipe C, Herrero JF, O’Brien JA, Palmer JA, Doyle CA, Smith AJH, Laird JMA, Belmonte C, Cervero F, Hunt SP. Altered nocieption, analgesia and aggression in mice lacking the receptor for substance P. Nature. 1998; 392:394-397. [PubMed: 9537323]

237. Dunn AJ, Berridge CW. Physiological and behavioral responses to corticotropin-releasing factor administration: is CRF a mediator of anxiety or stress responses? Brain Res Rev. 1990; 15:71100. [PubMed: 1980834]

238. Vale W, Spiess J, Rivier C, Rivier J. Characterization of a 41-residue ovine hypothalamic peptide that stimulates secretion of corticotropin and $\beta$-endorphin. Science. 1981; 213:1394-1397. [PubMed: 6267699]

239. Lowry CA, Moore FL. Regulation of behavioral responses by corticotropin-releasing factor. Gen Comp Endocrinol. 2006; 146:19-27. [PubMed: 16426606]

240. Hostetler CM, Ryabinin AE. The CRF system and social behavior: a review. Front Neurosci. 2013; 7:92. [PubMed: 23754975]

241. Mele A, Cabib S, Oliverio A, Melchiorri P, Puglisi-Allegra S. Effects of corticotropin releasing factor and sauvagine on social behavior of isolated mice. Peptides. 1987; 8:935-938. [PubMed: 3501578]

242. Carpenter RE, Korzan WJ, Bockholt C, Watt MJ, Forster GL, Renner KJ, Summers CH. Corticotropin releasing factor influences aggression and monoamines: modulation of attacks and retreats. Neuroscience. 2009; 158:412-425. [PubMed: 18992791]

243. Elkabir DR, Wyatt ME, Vellucci SV, Herbert J. The effects of separate or combined infusions of corticotrophin-releasing factor and vasopressin either intraventricularly or into the amygdala on aggressive and investigative behaviour in the rat. Regul Pept. 1990; 28:199-214. [PubMed: 2343163]

244. Farrokhi C, Blanchard DC, Griebel G, Yang M, Gonzales C, Markham C, Blanchard RJ. Effects of the CRF1 antagonist SSR125543A on aggressive behaviors in hamsters. Pharmacol Biochem Behav. 2004; 77:465-469. [PubMed: 15006456]

245. Cheng SY, Delville Y. Play fighting and corticotropin-releasing hormone in the lateral septum of golden hamsters. Neuroscience. 2010; 169:236-245. [PubMed: 20417693]

246. Backström T, Pettersson A, Johansson V, Winberg S. CRF and urotensin I effects on aggression and anxiety-like behavior in rainbow trout. J Exp Biol. 2011; 214:907-914. [PubMed: 21346117]

247. Quadros IM, Hwa LS, Shimamoto A, Carlson J, DeBold JF, Miczek KA. Prevention of alcoholheightened aggression by CRF-R1 antagonists in mice: critical role for DRN-PFC serotonin pathway. Neuropsychopharmacology. 2014; 39:2874-2883. [PubMed: 24917195] 
248. Anderson BM, Stevens MC, Meda SA, Jordan K, Calhoun VD, Pearlson GD. Functional imaging of cognitive control during acute alcohol intoxication. Alcohol Clin Exp Res. 2011; 35:156-165. [PubMed: 20958334]

249. Virkkunen M. Urinary free cortisol secretion in habitually violent offenders. Acta Psychiatr Scand. 1985; 72:40-44. [PubMed: 2994368]

250. Hibbeln JR, Bissette G, Umhau JC, George DT. Omega-3 status and cerebrospinal fluid corticotrophin releasing hormone in perpetrators of domestic violence. Biol Psychiatry. 2004; 56:895-897. [PubMed: 15576068]

251. Lutz PE, Kieffer BL. The multiple facets of opioid receptor function: implications for addiction. Curr Opin Neurobiol. 2013; 23:473-479. [PubMed: 23453713]

252. MacHin AJ, Dunbar RIM. The brain opioid theory of social attachment: A review of the evidence. Behaviour. 2011; 148:985-1025.

253. Braud WG, Weibel JE. Acquired stimulus control of drug-induced changes in aggressive display in Betta splindens . J Exp Anal Behav. 1969; 12:773-777. [PubMed: 5391062]

254. Avis HH, Peeke HVS. Differentiation by morphine of two types of aggressive behavior in the convict cichlid (Cichlasoma nigrofasciatum). Psychopharmacologia. 1975; 43:287-288. [PubMed: 1237915]

255. Faisal M, Chiappelli F, Ahmed II, Cooper EL, Weiner H. Social confrontation "stress" in aggressive fish is associated with an endogenous opioid-mediated suppression of proliferative response to mitogens and nonspecific cytotoxicity. Brain Behav Immun. 1989; 3:223-233. [PubMed: 2611410]

256. Wikler A. Studies on the action of morphine on the central nervous system of cat. J Pharmacol Exp Ther. 1944; 80:176-187.

257. Cronin GM, Wiepkema PR, van Ree JM. Endogenous opioids are involved in abnormal stereotyped behaviours of tethered sows. Neuropeptides. 1985; 6:527-530. [PubMed: 4080112]

258. Dyakonova V, Schurmann FW, Sakharov DA. Effects of opiate ligands on intraspecific aggression in crickets. Peptides. 2002; 23:835-841. [PubMed: 12084513]

259. Espert R, Navarro JF, Salvador A, Simon VM. Effects of morphine hydrochloride on social encounters between male mice. Aggress Behav. 1993; 19:377-383.

260. Winslow JT, Miczek KA. Naltrexone blocks amphetamine-induced hyperactivity, but not disruption of social and agonistic behavior in mice and squirrel monkeys. Psychopharmacology. 1988; 96:493-499. [PubMed: 3149772]

261. Rodgers RJ, Hendrie CA. Social conflict activates status-dependent endogenous analgesic or hyperalgesic mechanisms in male mice: Effects of naloxone on nociception and behaviour. Physiol Behav. 1983; 30:775-780. [PubMed: 6308696]

262. Dyakonova V, Schormann FW, Sakharov DA. Social aggressiveness of female and subordinate male crickets is released by opiate receptor antagonist. Acta Biol Hung. 2000; 51:363-367. [PubMed: 11034161]

263. Borg S, Kvande H, Rydberg U, Terenius L, Wahlstrom A. Endorphin levels in human cerebrospinal fluid during alcohol intoxication and withdrawal. Psychopharmacology. 1982; 78:101-103. [PubMed: 6817362]

264. Miczek KA, Thompson ML, Shuster L. Opioid-like analgesia in defeated mice. Science. 1982; 215:1520-1522. [PubMed: 7199758]

265. Siegfried B, Frischknecht HR. Place avoidance learning and stress-induced analgesia in the attacked mouse: role of endogenous opioids. Behav Neural Biol. 1989; 52:95-107. [PubMed: 2757588]

266. Konicki PE, Schulz SC. Rationale for clinical trials of opiate antagonists in treating patients with personality disorders and self-injurious behavior. Psychopharmacol Bull. 1989; 25:556-563. [PubMed: 2698484]

267. Dinwiddie, T. Effects of ethanol on neurotransmitter systems. In: Gruol, D.; Israel, Y., editors. Alcohol and Alcohol Actions Lecture Series. Austin: Research Society on Alcoholism; 2001.

268. Meyer H. Zur Theorie der Alkoholnarkose. I. Welche Eigenschaft der Anästhetica bedingt ihre narkotische Wirkung? Naunyn Schmiedebergs Arch Pharmakol Exp Pathol. 1899; 42:109-118. 
269. Meyer H. Zur Theorie der Alkoholnarkose. III. Der Einfluss wechselnder Temperatur auf Wirkungsstärke und Theilungscoefficient der Narcoticaarkose. Naunyn Schmiedebergs Arch Pharmakol Exp Pathol. 1901; 46:338-346.

270. Overton, E. Studien über die Narkose: zugleich ein Beitrag zur allgemeinen Pharmakologie. Jena: Gustav Fischer; 1901.

271. Lovinger DM. Alcohols and neurotransmitter gated ion channels: past, present and future. Naunyn Schmiedebergs Arch Pharmacol. 1997; 356:267-282. [PubMed: 9303562]

272. Franks NP, Lieb WR. Do general anaesthetics act by competitive binding to specific receptors? Nature. 1984; 310:599-601. [PubMed: 6462249]

273. Allan AM, Harris RA. Gamma-Aminobutyric acid agonists and antagonists alter chloride flux across brain membranes. Mol Pharmacol. 1986; 29:497-505. [PubMed: 3010078]

274. Mihic SJ, Ye Q, Wick MJ, Koltchine VV, Krasowski MA, Finn SE, Mascia MP, Valenzuela CF, Hanson KK, Greenblatt EP, Harris RA, Harrison NL. Sites of alcohol and volatile anaesthetic action on GABA $_{A}$ and glycine receptors. Nature. 1997; 389:385-389. [PubMed: 9311780] 


\section{Evolution of concepts of anesthetic and ethanol action 1899-1901 1980s-90s}

\section{Membrane/lipid theories of anesthesia \\ The Meyer-Overton Correlation Meyer 1899, 1901; Overton 1901}

Review: Lovinger, 1997

\section{Luciferase \\ Franks \& Lieb 1984}

\section{NMDA R}

Lovinger et al. 1989; Hoffman et al. 1989
$\mathrm{GABA}_{\mathrm{A}} \mathbf{R}$

Allan \& Harris 1986; Suzdak et al. 1986; Ticku et al. 1986
GABA $_{A}$ /glycine $R$ Mihic et al. 1997

Figure 1.

Theories of ethanol action at the cellular level. Adapted from Dunwiddie $2001 ;{ }^{267}$ works cited. $26,27,32,34,268-274$ 


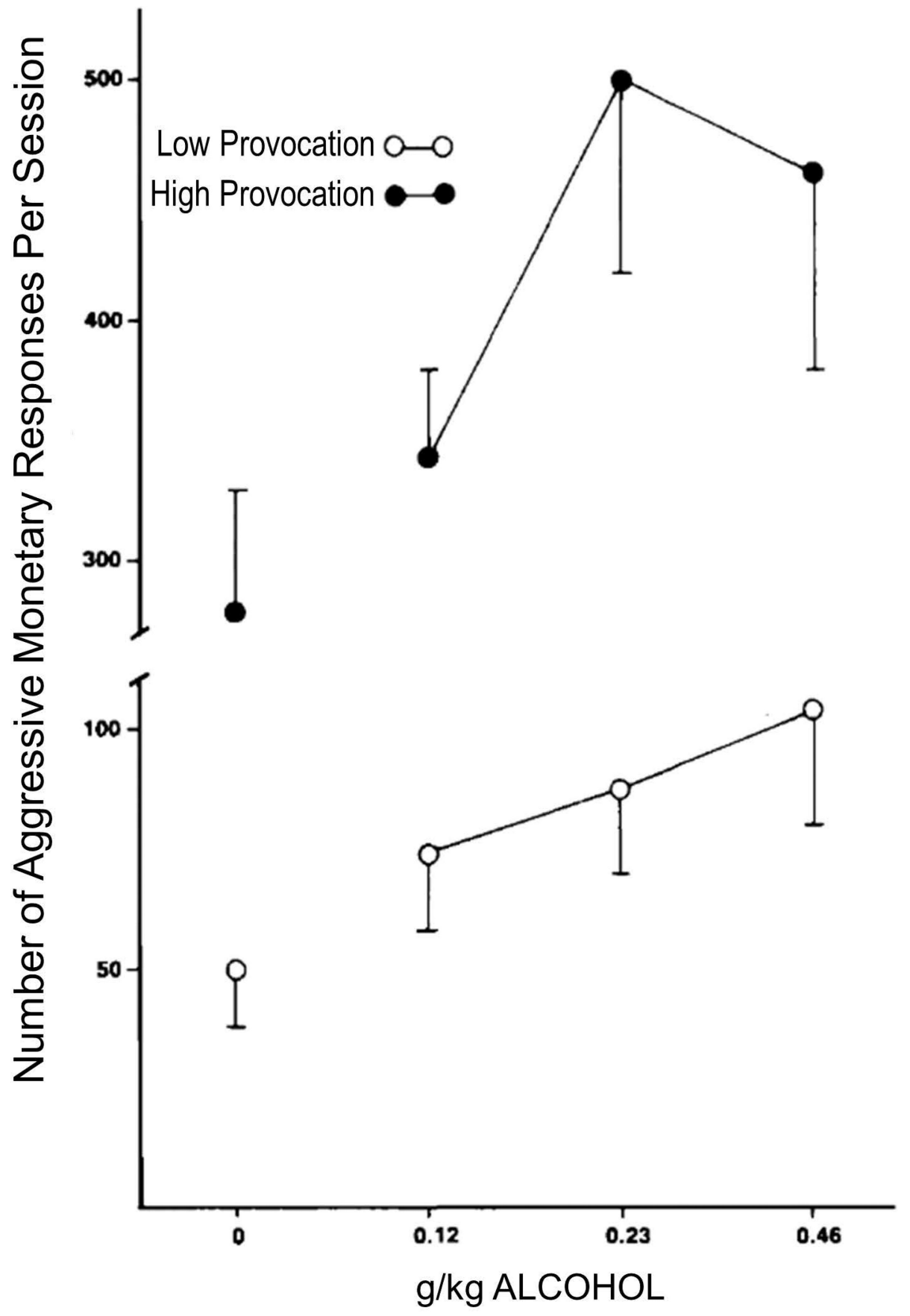

Figure 2.

Number of aggressive monetary subtraction responses per session after the administration of placebo or 3 different doses of alcohol. Data points represent means of 4 subjects each in the low- and high-provocation conditions, and vertical lines are \pm 1 SEM. From Cherek, et al. ${ }^{79}$ 

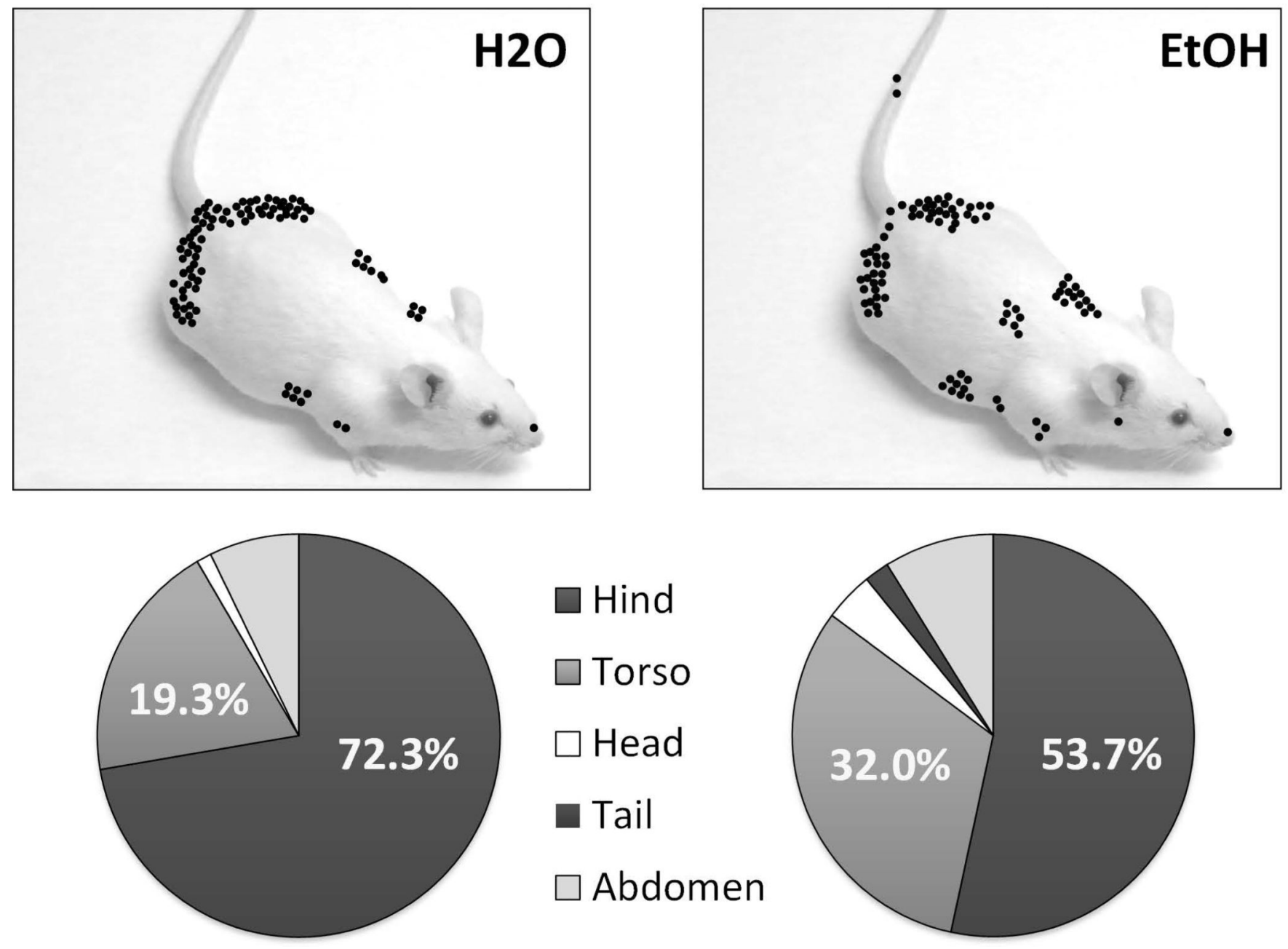

Figure 3.

Target areas of bites inflicted by resident mice after oral self-administration of water (left) or $1 \mathrm{~g} / \mathrm{kg}$ ethanol (right). From Newman, et al. in preparation. 


\section{Proportion of mice showing aggression during withdrawal}

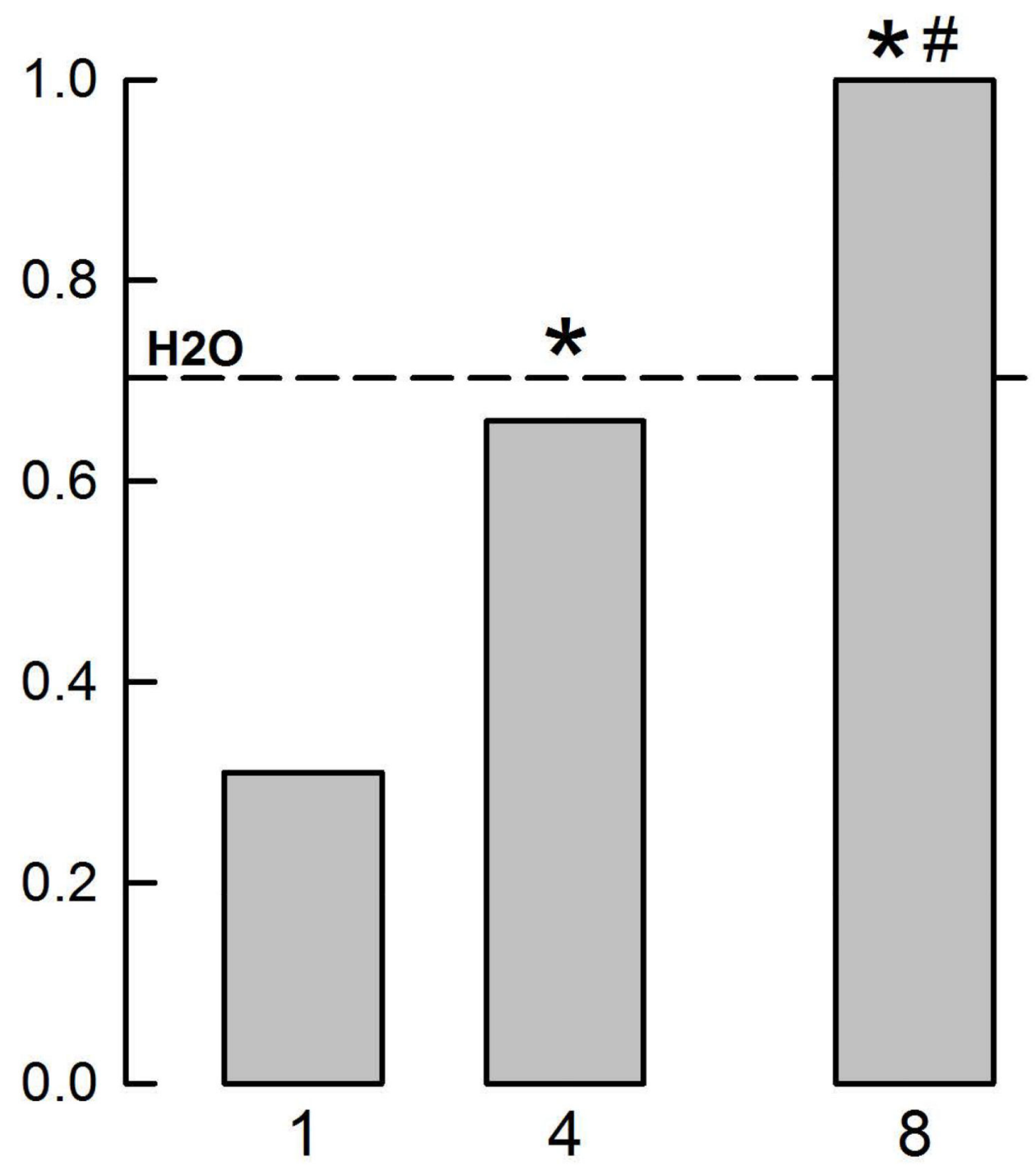

Weeks of Intermittent Alcohol

Figure 4.

Proportion of mice showing aggression during 8 hour withdrawal from intermittent alcohol access after 1,4 , or 8 weeks of exposure. The dashed line represents the average of water drinkers across age-matched groups. ${ }^{*} P<0.05$ vs. wk 1 ; ${ }^{\#} P<0.05$ vs. $\mathrm{H}_{2} \mathrm{O}$. From Hwa, et $a l .{ }^{77}$ 


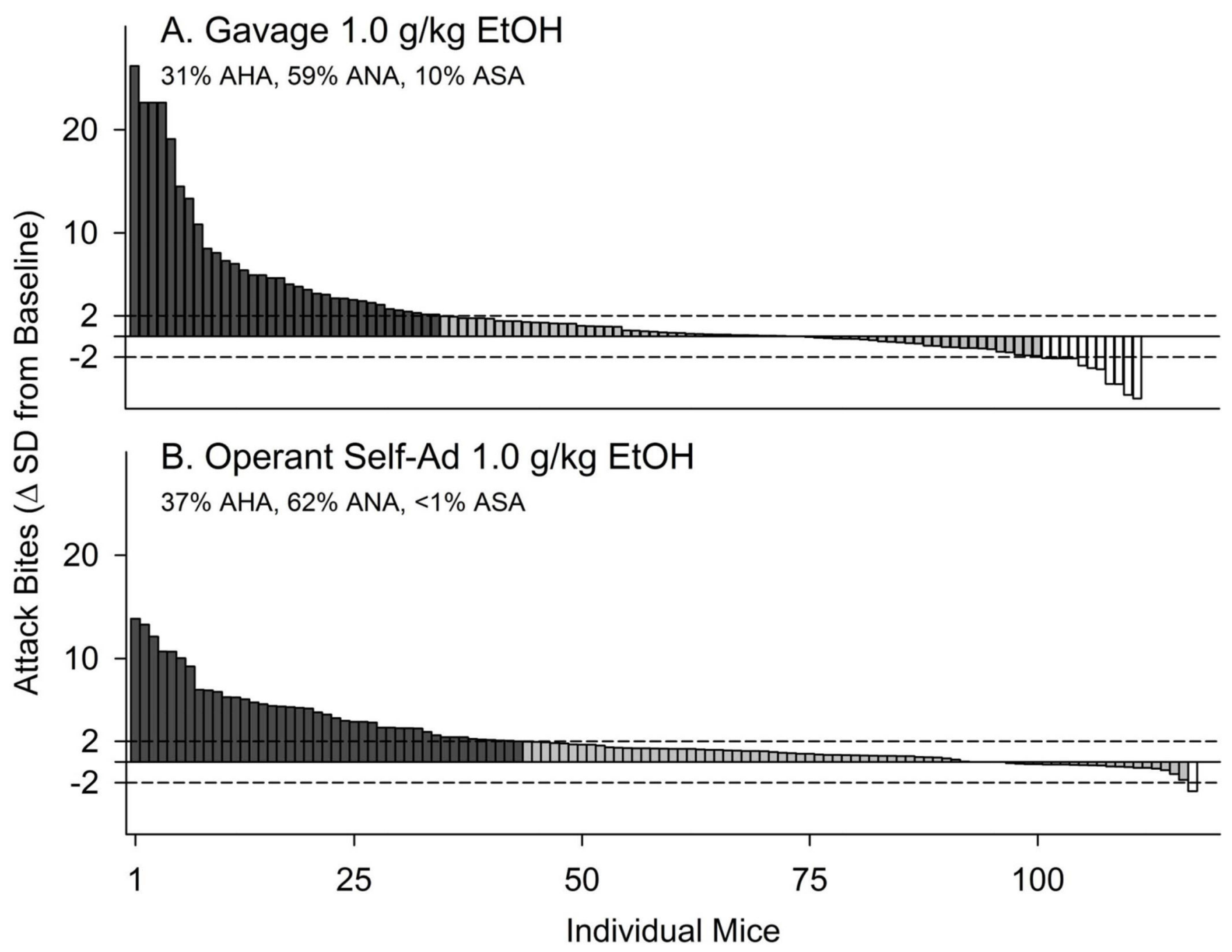

Figure 5.

Histogram representing the proportion and individual magnitude of alcohol-heightened aggression after gavage (A) or operant self-administration (B) of $1.0 \mathrm{~g} / \mathrm{kg}$ alcohol. Dark vertical bars represent outbred CFW mice whose average frequency of attack bites after 1 $\mathrm{g} / \mathrm{kg}$ alcohol exceeds their baseline levels of aggression by > 2 SD (alcohol-heightened aggression, or AHA). Gray vertical bars represent mice whose aggressive behavior is not significantly altered by $1 \mathrm{~g} / \mathrm{kg}$ alcohol (alcohol non-heightened aggression, or ANA), and white vertical bars represent mice whose aggressive behavior after $1 \mathrm{~g} / \mathrm{kg}$ alcohol is reduced by $>2$ SD (alcohol-suppressed aggression, or ASA). Dotted horizontal lines represent a $95 \%$ confidence interval, \pm 2 SD from average baseline. From Miczek, et al. ${ }^{86}$ 


\section{Ethanol Intake} (g/kg)

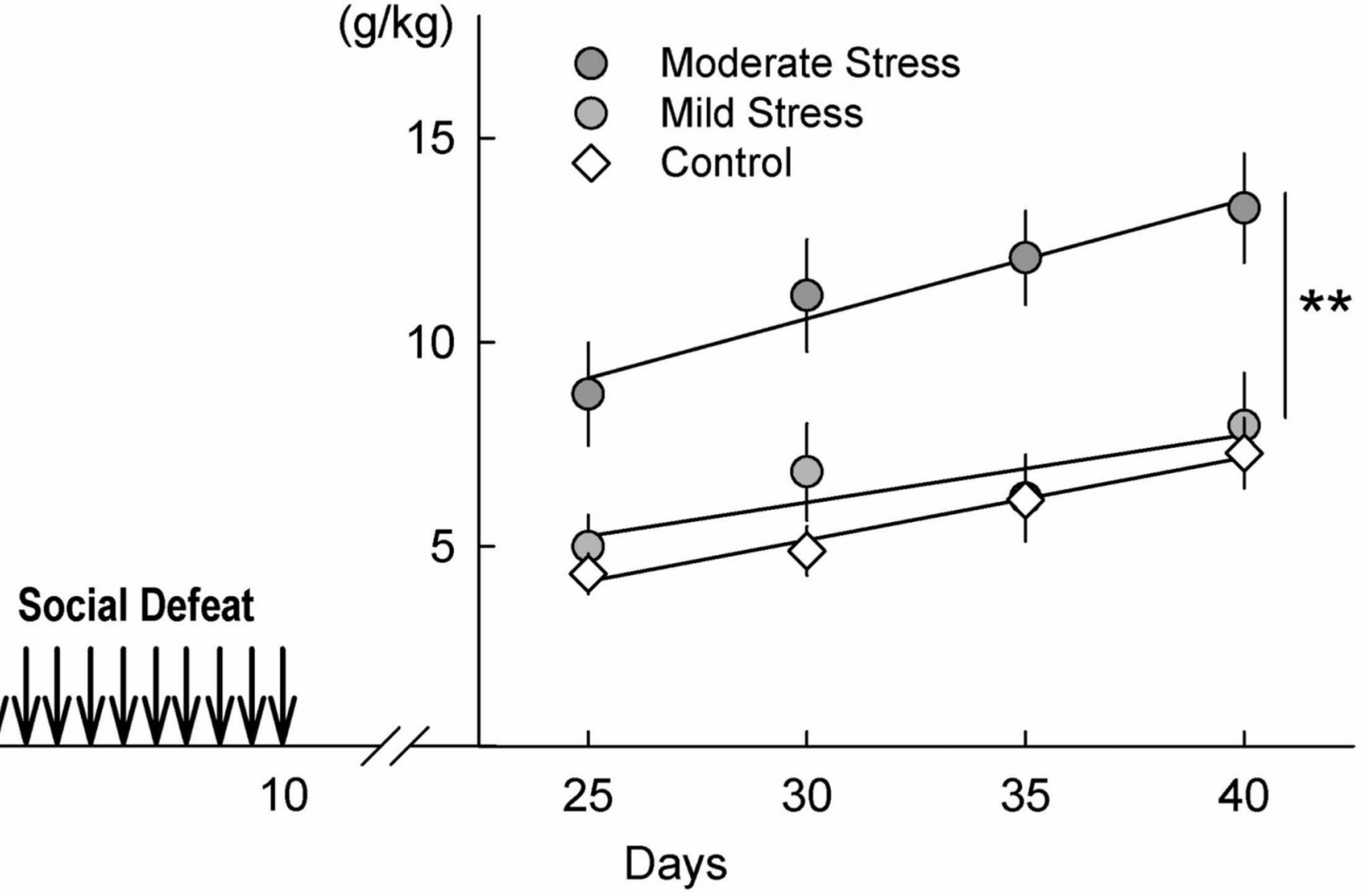

Figure 6.

Twenty percent ethanol intake ( $\mathrm{g} / \mathrm{kg} /$ day) during continuous access two-bottle choice over the course of 20 days, starting 10 days after moderate $(n=39)$ or mild $(n=19)$ social defeat stress (control, $n=29$ ). Data points are 5-day averages \pm SEM beginning on the day indicated (i.e., 25 signifies days 25-29); ${ }^{*} P<0.001$ compared to controls. From Norman, et al. ${ }^{120}$ 

A. Baseline
B. Fight
C. FI
D. FI and Fight

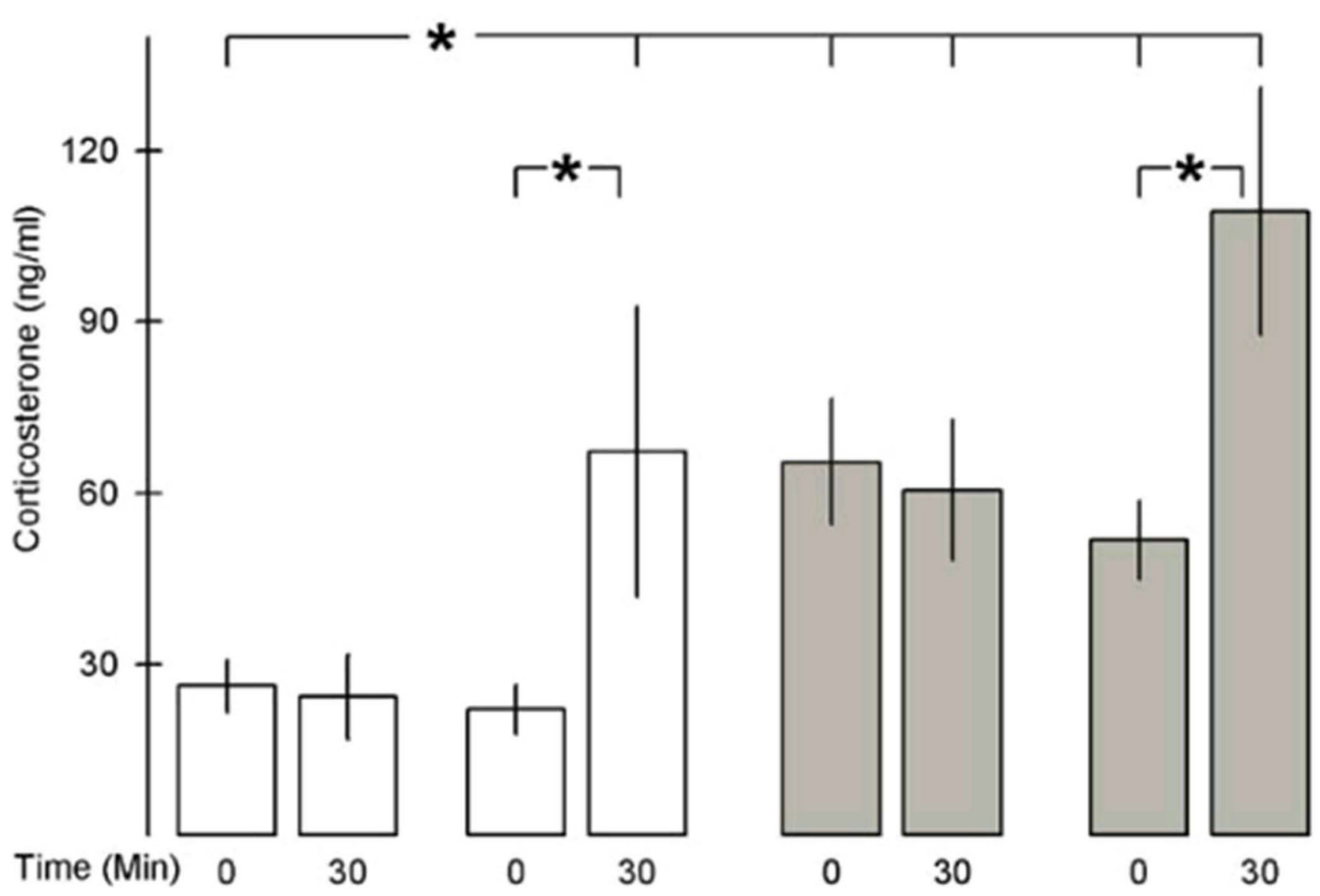

Figure 7.

The effects of fixed interval schedule of reinforcement (FI) performance and fighting on corticosterone levels. Mean plasma corticosterone levels (ng/ml) are shown from resident mice immediately or $30 \mathrm{~min}$ after four different events. (A) Baseline corticosterone levels at the time of day when mice are conditioned to respond on an FI10 schedule; (B) levels after a brief attack flurry; (C) levels after completing the FI, but when no fight has occurred; and (D) levels after completing the FI and engaging in a brief fight. The open bars represent corticosterone levels when the mice have not responded on the FI10, and the filled gray bars represent levels after completion of the FI10. Vertical lines indicate \pm 1 SEM; $* P<0.05$. From Fish, et al. ${ }^{137}$ 


\section{Attack Bite Frequency}

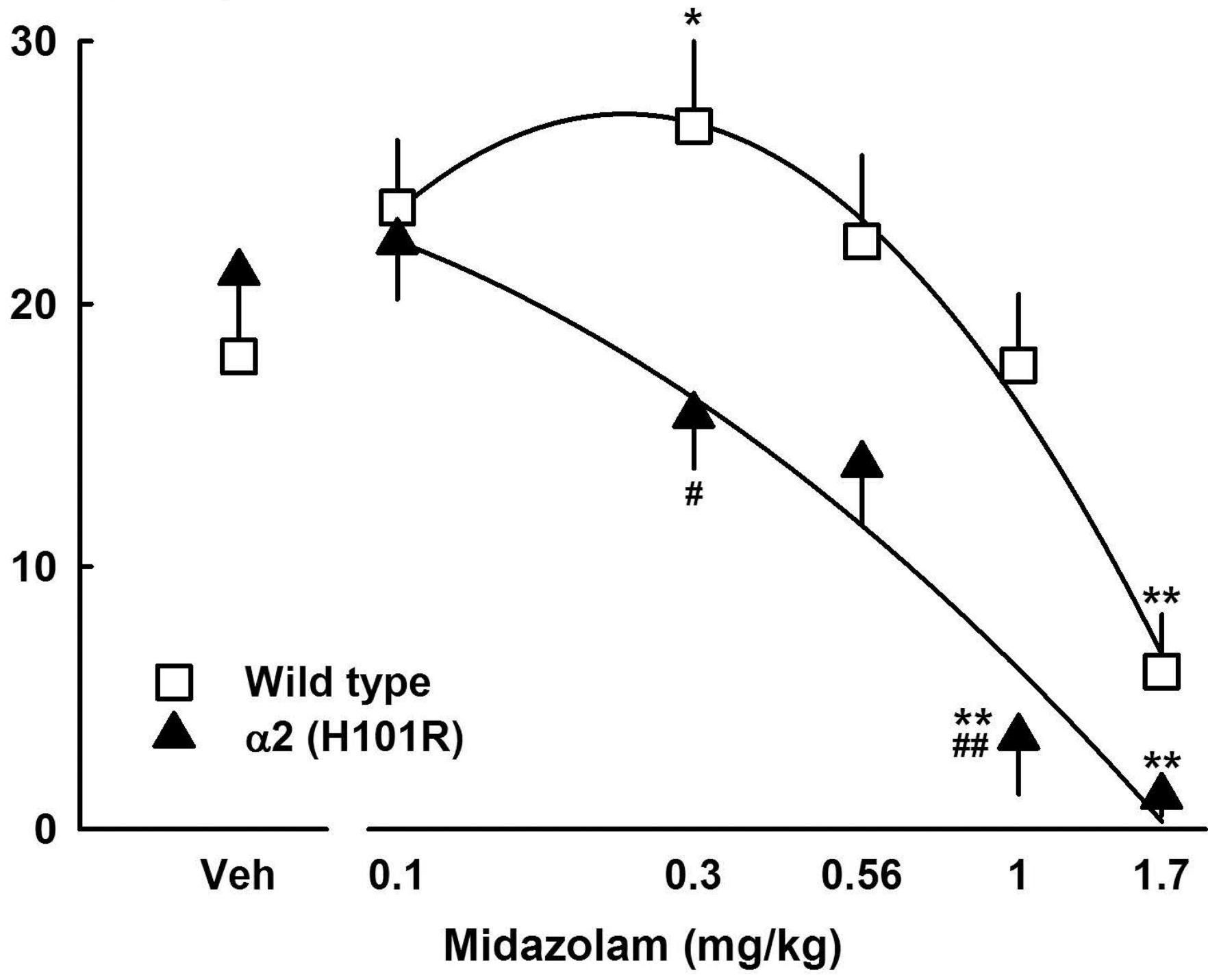

Figure 8.

Attack bite frequencies in a novel environment following systemic midazolam treatment of wild-type C57BL6/J and benzodiazepine-insensitive Gabra2 (H101R) point-mutated mice. Values are means $\pm \mathrm{SEM} ;{ }^{*} P<0.05$, ${ }^{*} * P<0.01$ compared to vehicle; ${ }^{\#} P<0.05,{ }^{\# \#} P<0.01$ compared to wild type. From Newman, et al. ${ }^{182}$ 


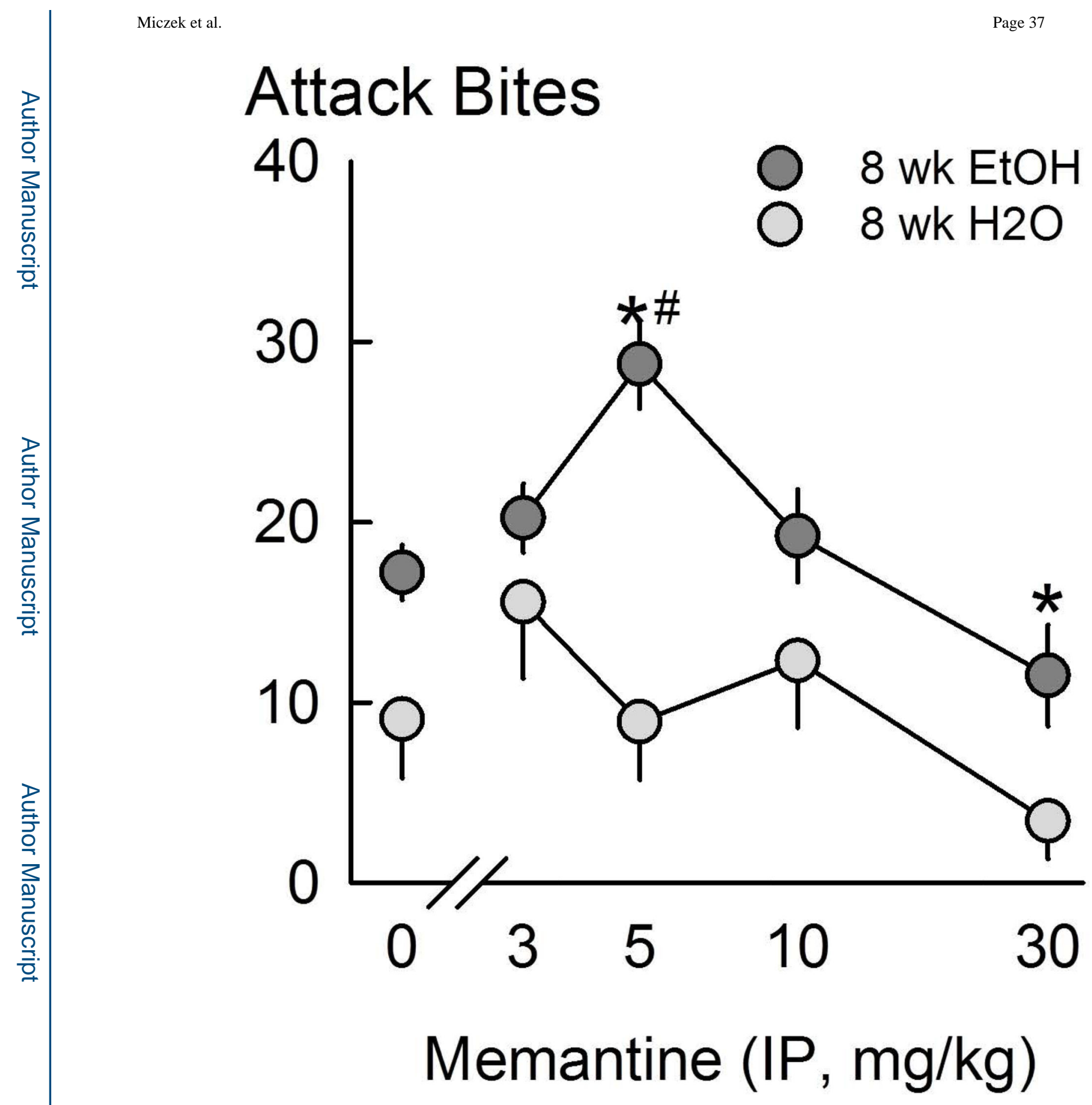

Figure 9.

Attack bites during 6-8 h withdrawal from 8 weeks of intermittent alcohol access after treatment with the NMDA receptor antagonist memantine (0-30 mg/kg, i.p.). Black dots represent alcohol drinkers and white dots represent water drinkers. Values are means \pm SEM; ${ }^{*} P<0.05$ vs. vehicle; ${ }^{\#} P<0.05$ vs. H2O. From Hwa, et al. ${ }^{77}$ 


\section{Table 1}

Estimates of association between alcohol consumption and homicide rates, hazardous drinking pattern score and estimated fraction of homicides attributable to alcohol consumption (from Rossow and Bye, 2013 ${ }^{3}$ )

\begin{tabular}{|c|c|c|c|c|}
\hline Author(s) & $\begin{array}{l}\text { Country/area, } \\
\text { period }\end{array}$ & $\begin{array}{l}\text { Parameter } \\
\text { estimate } \\
\text { (SE) }\end{array}$ & $\begin{array}{l}\text { Level of } \\
\text { hazardous } \\
\text { drinking pattern }\end{array}$ & $\begin{array}{l}\text { Attributable } \\
\text { fraction } \\
\text { (AF) }\end{array}$ \\
\hline Rossow $(2001)^{274}$ & $\begin{array}{l}\text { North Europe, } \\
1950-1995\end{array}$ & $\begin{array}{l}0.124 \\
(0.038)\end{array}$ & High & 0.50 \\
\hline Rossow (2001) & $\begin{array}{l}\text { Central Europe, } \\
\text { 1950-1995 }\end{array}$ & $\begin{array}{l}0.085 \\
(0.023)\end{array}$ & Medium & 0.55 \\
\hline Rossow (2001) & $\begin{array}{l}\text { South Europe, } \\
1950-1995\end{array}$ & $\begin{array}{l}0.055 \\
(0.017)\end{array}$ & Low & 0.61 \\
\hline Rossow $(2004)^{275}$ & $\begin{array}{l}\text { Canada, Ontario, } \\
\text { 1950-1995 }\end{array}$ & $\begin{array}{l}0.093 \\
(0.040)\end{array}$ & Medium & 0.58 \\
\hline Rossow (2004) & $\begin{array}{l}\text { Canada, Quebec, } \\
\text { 1950-1995 }\end{array}$ & $\begin{array}{l}-0.030 \\
(0.077) \mathrm{ns}\end{array}$ & Low & na \\
\hline Bye $(2008)^{276}$ & $\begin{array}{l}\text { Belarus and Russia, } \\
\text { 1959-2004 }\end{array}$ & $\begin{array}{l}0.072 \\
(0.016)\end{array}$ & Very high & 0.57 \\
\hline Bye (2008) & $\begin{array}{l}\text { Former Czechoslovakia, } \\
\text { 1953-1989 }\end{array}$ & $\begin{array}{l}0.117 \\
(0.067)\end{array}$ & Medium & 0.73 \\
\hline $\begin{array}{l}\text { Landberg and } \\
\text { Norström }(2011)^{277}\end{array}$ & $\begin{array}{l}\text { United States, } \\
\text { 1950-2002 }\end{array}$ & $\begin{array}{l}0.094 \\
(0.044)\end{array}$ & Medium & 0.57 \\
\hline $\begin{array}{l}\text { Landberg and } \\
\text { Norström (2011) }\end{array}$ & $\begin{array}{l}\text { Russia, } \\
\text { 1959-1998 }\end{array}$ & $\begin{array}{l}0.081 \\
(0.015)\end{array}$ & Very high & 0.73 \\
\hline Norström (2011) $)^{278}$ & $\begin{array}{l}\text { United States, } \\
\text { 1950-2002, dry }\end{array}$ & $\begin{array}{l}0.035 \\
(0.047) \mathrm{ns}\end{array}$ & Low & na \\
\hline Norström (2011) & $\begin{array}{l}\text { United States, } \\
\text { 1950-2002, moderate }\end{array}$ & $\begin{array}{l}0.071 \\
(0.037)\end{array}$ & Medium & 0.51 \\
\hline Norström (2011) & $\begin{array}{l}\text { United States, } \\
\text { 1950-2002, wet }\end{array}$ & $\begin{array}{l}0.174 \\
(0.045)\end{array}$ & High & 0.80 \\
\hline Ramstedt $(2011)^{11}$ & $\begin{array}{l}\text { Australia, } \\
1950-2003\end{array}$ & $\begin{array}{l}0.075 \\
(0.028)\end{array}$ & Medium & 0.56 \\
\hline
\end{tabular}

ns, not significant; na, not applicable. 